\title{
Neanderthal Spatial Patterns and Occupation Dynamics: A Focus on the Central Region in Mediterranean Iberia
}

\author{
Aleix Eixea ${ }^{1,2}$. María Gema Chacón ${ }^{3,4,5,6} \cdot$ Amèlia Bargalló $^{7} \cdot$ Alfred Sanchis $^{8}$. \\ Francesca Romagnoli ${ }^{9}$. Manuel Vaquero ${ }^{3,4}$. Valentín Villaverde ${ }^{1,2}$
}

Published online: 4 August 2020

(C) Springer Science+Business Media, LLC, part of Springer Nature 2020

\begin{abstract}
This paper focuses on the study of some Middle Palaeolithic assemblages from Mediterranean Iberia to examine Neanderthal occupation patterns and territory management strategies, paying special attention to raw material procurement and technological behaviours, zooarchaeological data and microspatial patterning. The site occupation types are variable, and some of the results may have more importance than is immediately apparent, but there does not seem to be a single cultural, functional, temporal or environmental explanation. Rather, the wide variability in the technical behaviours observed can be explained with reference to the particular requirements of the populations in each specific region. The results obtained allow us to interrogate the data and, drawing comparisons with the southwest European context, establish an initial approach to Neanderthal subsistence strategies and mobility in a region so far little known in this regard.
\end{abstract}

Keywords Land use $\cdot$ Regional analysis $\cdot$ Neanderthal behaviour $\cdot$ Upper Pleistocene $\cdot$ Mediterranean Iberia

\section{Resumen}

En el siguiente trabajo se estudian varios conjuntos pertenecientes al Paleolítico medio procedentes del mediterráneo peninsular ibérico con el objetivo de examinar los patrones de ocupación y las estrategias de gestión del territorio. Se presta especial atención al abastecimiento de las materias primas y los comportamientos tecnológicos, los datos procedentes de la fauna y los análisis microespaciales. La variabilidad en los tipos de ocupación de los distintos conjuntos nos muestra una gran diversidad y una multitud de factores, aunque no parece tener una sola explicación cultural, funcional, temporal o ambiental. Más bien son explicaciones que responden a una amplia variabilidad en los comportamientos técnicos observados y que se explican en función de las propias necesidades de las poblaciones dentro de cada región. Los

Aleix Eixea

alejo.eixea@uv.es

Extended author information available on the last page of the article 
resultados obtenidos nos permiten analizar los datos y compararlos en el contexto del sudoeste de Europa de cara a elaborar un primer enfoque de las estrategias de subsistencia de los neandertales y su movilidad en una región hasta ahora poco conocida desde este punto de vista.

Palabras clave Uso del espacio · Análisis regional · Comportamiento Neandertal · Pleistoceno superior · Mediterráneo Ibérico

\section{Introduction}

The different modes of territorial organisation of Neanderthal populations are one of the central topics in current scientific discussion of the Middle and Upper Pleistocene. Compared with Central and Eastern Europe, findings from Western Europe remain scarce and is still difficult to produce a general scenario for macro-regional spatial patterns (Geneste 1985; Gamble 1986; Szmidt 2003; Burke 2006; Andrefsky 2009; Turq et al. 2013; Haws et al. 2020). Much of the debate is focused on the behavioural differences between Neanderthals and Anatomically Modern Humans $(\mathrm{AMH})$, and their capacity to exploit their territory in relation to spatial organisation and planning (Chase 1986, 1988; David and Enloe 1993; Gaudzinski 2000; Grayson and Delpech 2002; d'Errico 2003; Costamagno et al. 2006). A distinction between occupational patterns and the use of space is based on regional data, with special reference to factors such as climate, mineral and animal resources, and environment and site morphology (Fiore et al. 2004; Delagnes and Meignen 2006; Costamagno et al. 2006; Rendu 2007; Patou-Mathis 2000; Daujeard and Moncel 2010; Delagnes and Rendu 2011; Daujeard et al. 2012; Kitagawa et al. 2012; Conard et al. 2012). The aim of this paper is to compare different sites from the Mediterranean Iberian Peninsula from this point of view, in order to understand the different processes through which Neanderthal groups settled in this territory, and to initiate comparison with the frameworks of nearby areas.

\section{Geographical and Chronological Context of the Sites}

The geographical area studied is the central region of Mediterranean Iberia, which has a narrow and elongated morphology with a land boundary of $840 \mathrm{~km}$ and a coast length of $518 \mathrm{~km}$ (Fig. 1). This geographical area is the result of alpine folding caused by the pressure of the African plate against the Eurasian plate. We find three different environments here: the coastal plains; the Iberian system, with a dominant NW-SE structural direction, located in the northern half; and the Baetic range, with a dominant SW-NE structural direction, located in the southern half. Although most of this territory is mountainous, the summits are not very high, corresponding with the foothills of the Iberian ensemble. The mountainous relief can be divided into three zones: 


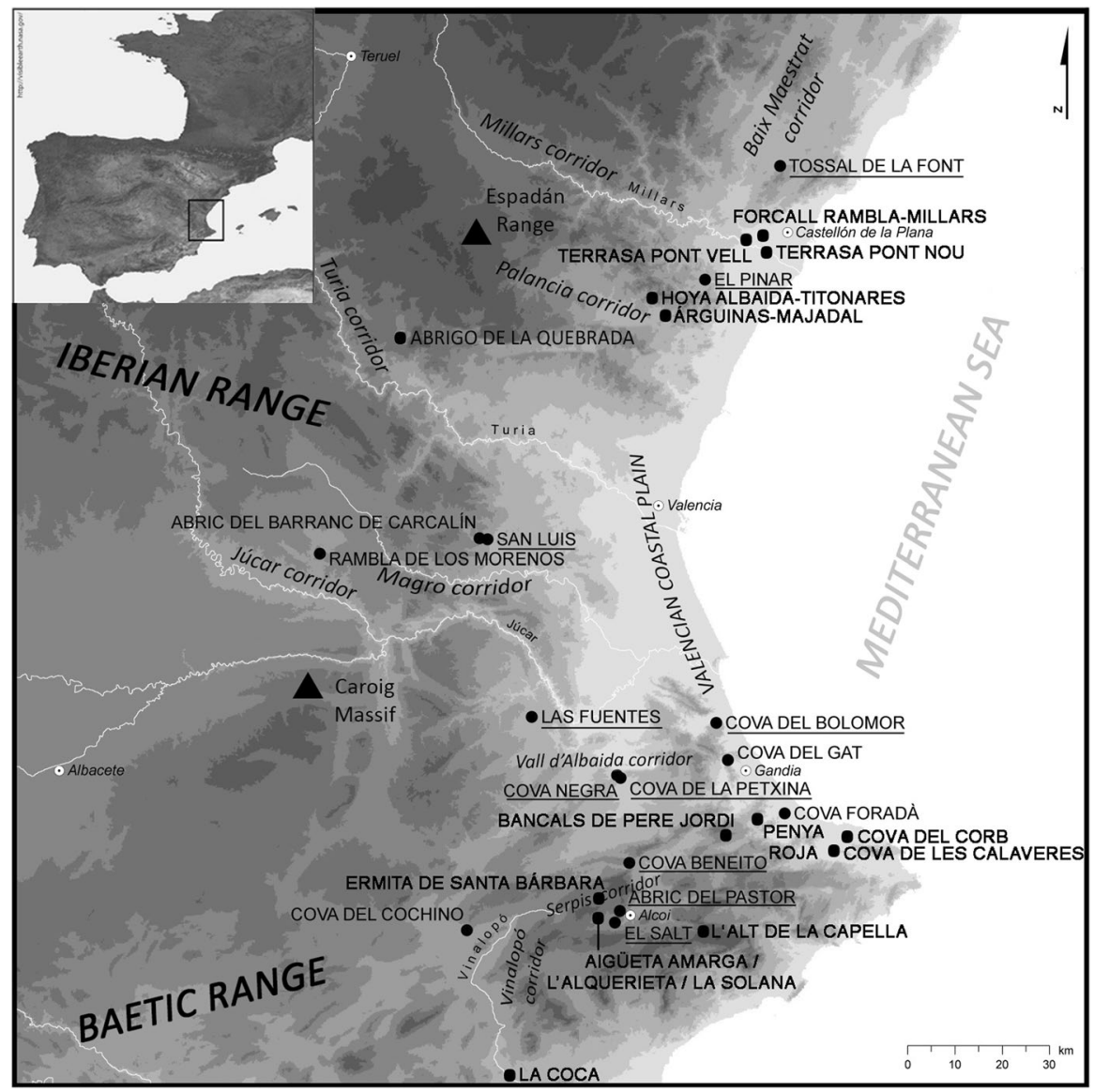

Fig. 1 Location of the main Middle Palaeolithic sites and geographical features

a. Valencian Iberian range: running NW-SE and composed of elevated mountains with heights above $2000 \mathrm{~m}$. The material is mainly limestone, due to the fact that it is an intermediate mountain range formed by secondary materials deposited on the eastern edge of the Iberian Plateau and raised in the Alpine orogenesis. The tabular relief forms very high buttes with deep grooves in which the hydrographic network fits.

b. Valencian Baetic range: starting in the Survalenciana fault and trending SW-NE. This relief is steep and with deep valleys.

c. Coastal plain: formed by quaternary materials deposited by rivers.

The rivers belong to the Mediterranean slope and they have their source in the mountains near the coast. They are short, with irregular channels, and are scarce due to lack of rainfall, small basins and the unevenness of their path. The waters 
of the Valencian territory are divided between three large hydrographic basins: the Turia, the Júcar and the Segura.

The Valencian territory is articulated by natural corridors which facilitate human and animal displacements throughout the central Iberian Mediterranean. Several works investigating the relationship between humans and their physical environment in Palaeolithic contexts (Aura et al. 1993 and bibliography therein) highlight the Baix Maestrat and the Millars corridor in the north; the Turia, Magro and the Canal de Navarrés corridors in the centre; and the Vall d'Albaida, Vinalopó and Vega Baja corridors in the south. This is an area in which a large number of cavities and rock shelters are concentrated, many with rich Palaeolithic sequences (Villaverde 1992; Fernández Peris 1994; Vicente et al. 2015).

Middle Palaeolithic deposits are numerous in this region. Leaving aside those on which there is scant information, they number more than forty. They are unevenly distributed, concentrated mainly in the south of the province of Valencia and in the north of the province of Alicante. Although almost half are open-air sites, documentation is limited to the lithic evidence, with very little information on the fauna or chronology, either because of conservation problems or because they have not been properly excavated. These features, coupled with the importance of the human remains recovered (Arsuaga et al. 2007, 2012) and the amplitude of the chronological sequence, mean that we will focus on those sets that provide data related to patterns in the use of space, economy and the management of lithic resources. Our attention is directed, therefore, to the deposits and levels below (listed from north to south).

\section{El Pinar}

El Pinar is an open air site, located in the centre of a large esplanade totally surrounded by mountains that vary between 200 and $220 \mathrm{~m}$ in height. Stratigraphically, it shows a first level of terrace with sands and gravels that increase in thickness towards the base. The transition to the underlying Level II shows erosive contact. Level II is composed of very plastic, sterile red clays that rest on a reddish yellow clay layer, in the upper part of which is a level of siliceous gravels. The whole set rests on a hard gap that is somewhat rolled and heavily cemented. Thermoluminescence (TL) data obtained were taken from the clays, with a result of $116 \mathrm{ka} \pm 17 \mathrm{ka}$ and $113 \mathrm{ka} \pm 17 \mathrm{ka}$ (Ref. Wa-8/91 and Wa-9/91). Two other dating samples were taken immediately below and above the structure, with a result of $88 \mathrm{ka} \pm 13 \mathrm{ka}$ and 87 ka \pm 13 ka (Ref. Wa-6/91 and Wa-7/91) (Casabó and Rovira 1992) (Fig. 2; Table 1).

\section{Abrigo de la Quebrada}

Abrigo de la Quebrada is located on the left side of the Rambla de Ahillas canyon (Chelva, Valencia). The stratigraphy features a total of nine units distributed over a thickness of $3 \mathrm{~m}$. Level I is a disturbed unit resulting from the use of the rock shelter as a sheepfold in recent times. Below, Levels II through V and VII to IX show evidence of 


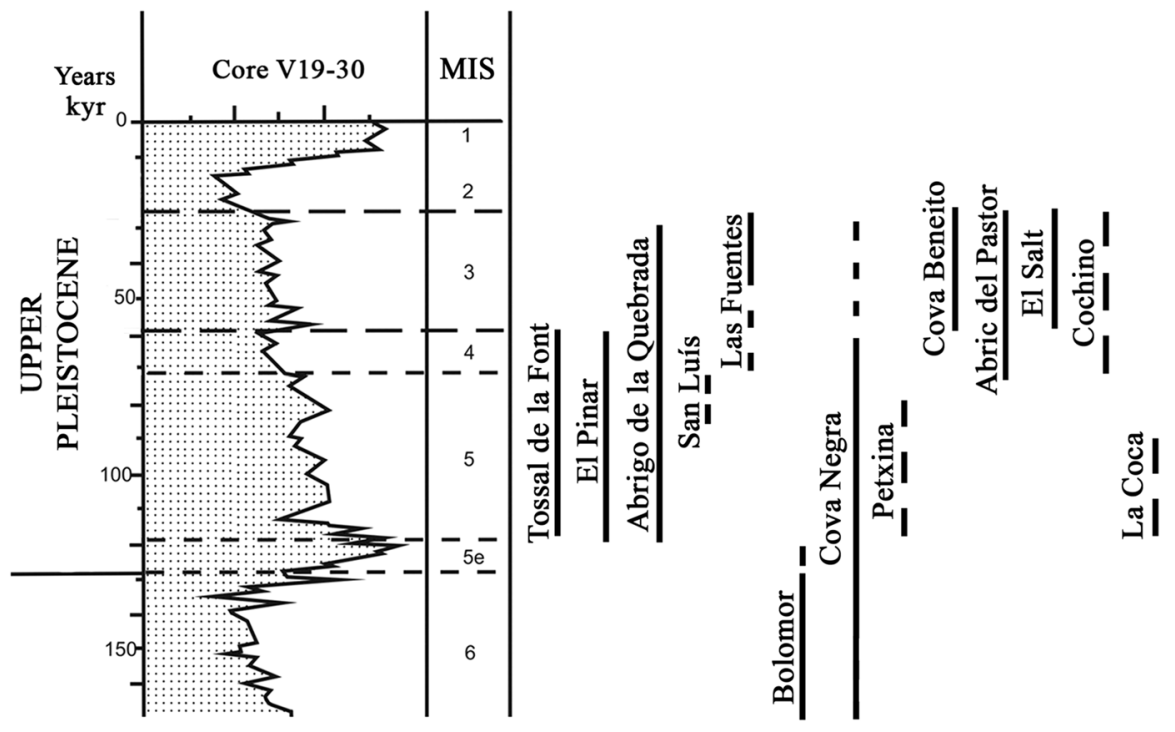

Fig. 2 Chronological framework of the Middle Palaeolithic sites (isotopic curve adapted from Gamble 1986). Continuous lines (absolute dates) and discontinuous lines (relative dates): Tossal de la Font (U/ Th: Gusi et al. 2013); El Pinar (TL: Casabó and Rovira 1992); Abrigo de la Quebrada (Radiocarbon: Villaverde et al. 2008; Eixea et al. 2011. OSL: Real et al. 2020); San Luís (Stratigraphy: Fernández Peris and Martínez Valle 1989); Las Fuentes (Radiocarbon: Aparicio 1981); Bolomor (U/Th, AAR and TL: Fernández Peris 2007); Cova Negra (TL: Arsuaga et al. 2007; Villaverde et al. 2014; ESR: Richard et al. 2019); Petxina (Stratigraphy: Villaverde 1984); Cova Beneito (Radiocarbon: Iturbe et al. 1993); Abric del Pastor (TL: Machado et al. 2013; ESR and OSL: Connolly et al. 2019); El Salt (TL and OSL: Galván et al. 2014); Cochino (Stratigraphy: Villaverde 1984); La Coca (Stratigraphy: Fernández Peris 1998)

human occupation. Level VI, almost $1 \mathrm{~m}$ thick, is sterile. Radiocarbon accelerator mass spectrometry (AMS) dating of charcoal fragments yielded ages of 40,500 $\pm 530 \mathrm{BP}$ (Ref. Beta-244,003; ABA-treated) and > 50,800 (Ref. OxA-24,854; ABOx-processed) for Level III; 43,930 \pm 750 BP (Ref. Beta-244,002; ABA-treated) and >51,600 (Ref. OxA-24,855; Ref. ABOx-processed) for Level IV; and >47,100 (Ref. OxA-25,583; ABOx-processed) for Level V. For archaeologically sterile Level VI, we have two optically stimulated luminescence (OSL) results on the feldspar fraction of $80 \mathrm{ka} \pm 4.7 \mathrm{ka}$ (C-L3900) and $83.2 \mathrm{ka} \pm 5.4 \mathrm{ka}$ (C-L3898), placing its deposition in Marine Isotope Stage (MIS) 5a or MIS5b. The chronometric data are consistent with: (a) it representing the c. 75,000 years between the minimum radiocarbon ages for Levels III-V and the onset of MIS5e, at one extreme; (b) it all belonging in the ten thousand years of MIS5a, at the other extreme; and (c) a number of intermediate scenarios (Villaverde et al. 2008; Eixea et al. 2011; Klasen 2015; Carrión et al. 2019).

\section{Cova del Bolomor}

Cova del Bolomor is located in the Valldigna Valley, a narrow and short valley bordered by the Iberian mountain range to the north and the Prebetic mountain range to 


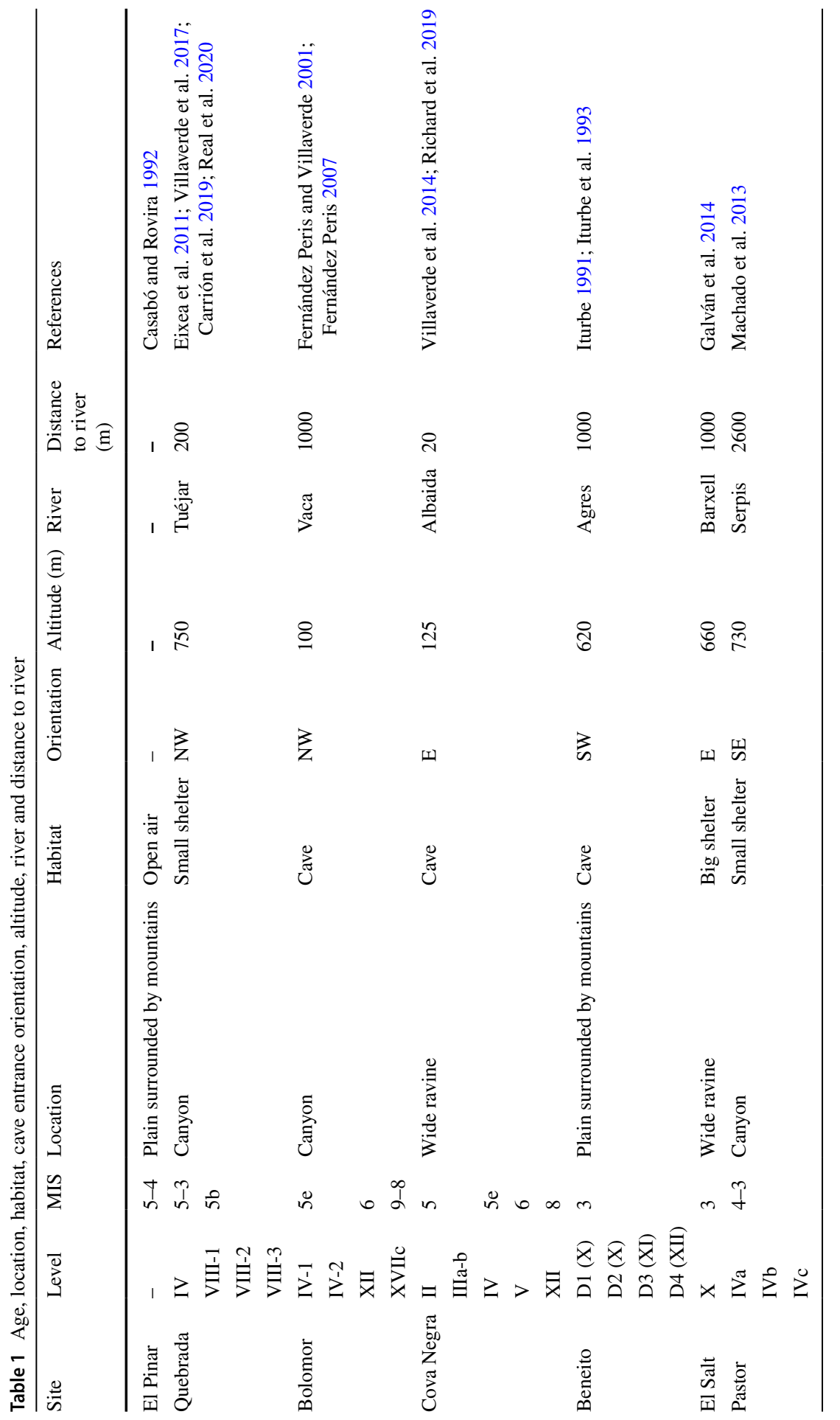


the south. The cave is situated approximately 100 masl. The stratigraphic sequence has been divided by a sedimentological study into 17 levels (numbered from the top of the deposit), with a maximum thickness of $14 \mathrm{~m}$ (Fumanal 1995). The karstic deposit of Bolomor has been dated by amino acid racemisation (AAR) and TL to between MIS 9 and MIS 5e. Several TL dates have been obtained: $121 \mathrm{ka} \pm 18 \mathrm{ka}$ for Level II, $225 \mathrm{ka} \pm 34 \mathrm{ka}$ for Level XIII and $233 \mathrm{ka} \pm 35 \mathrm{ka}$ for Level XIV. AAR dates have also been obtained: $228 \mathrm{ka} \pm 53 \mathrm{ka}$ for Level XIII and $525 \mathrm{ka} \pm 125 \mathrm{ka}$ for Level XVII. Therefore, Level IV involves an ante quem time of $121 \mathrm{ka} \pm 18 \mathrm{ka}$ from TL and magnetic susceptibility (Fernández Peris 2007).

\section{Cova Negra}

Cova Negra is located on the left bank of the Albaida River. The cave, which is situated some $17 \mathrm{~m}$ above the level of the river, is characterised by a large entrance and contains some $500 \mathrm{~m}^{2}$ of surface area. The stratigraphic sequence comprises 15 levels that span the Middle and Late Pleistocene, representing six sedimentary phases (Cova Negra Phase F to A). The new sequence suggests that the upper levels include removed materials (Middle and Upper Palaeolithic with Gravettian, Evolved Solutrean and Magdalenian pieces) belonging to MIS 2 and 4. Biostratigraphy and lithic assemblage show that Cova Negra phases F and E (Levels I to IV), in clearly erosional contact with the scrambled upper level, could be situated in the early Late Pleistocene. According to this proposal, the remaining phases of the sequence must be correlated with the Upper Middle Pleistocene. The determining factor in this attribution is the identification of Microtus brecciensis in phase D (Levels $\mathrm{V}$ to XII) and following lower phases C to A (Levels XIII to XV) (Villaverde et al. 2014; Richard et al. 2019).

\section{Cova Beneito}

Cova Beneito is a large rock shelter located on the left slope of the Agres River, a tributary of the Serpis. It opens on Miocene lands in an intermediary area between limestone and conglomerates. The zone is very abrupt and stony, with a very steep slope and clear gelifraction phenomena. The radiocarbon dating conducted on bone from Level D1 yielded results of 38,800 1900 (Ref. AA1387) and 30,160 \pm 1680 (Ref. Gif1387), the latter of which was probably rejuvenated by incomplete extraction of humic acids (Iturbe and Cortell 1987; Iturbe et al. 1993; Doménech 2005).

\section{El Salt}

El Salt is located in an open-air setting at 660 masl in the mountainous region of Alcoi (eastern area of the Prebetic System). Its Middle Palaeolithic sequence is composed of eight stratigraphic units (from SU XII to the middle of SU V) dated between $60.7 \mathrm{ka} \pm 8.9 \mathrm{ka}$ (Ref. ES 34) and 45.2 $\mathrm{ka} \pm 3.4 \mathrm{ka}$ (Ref. OSL 1), which are sheltered by a $38 \mathrm{~m}$ high Paleocene limestone wall covered by travertine. The 
context analysed in this study has been isolated within the upper part of SU X, dated to $52.3 \mathrm{ka} \pm 4.6 \mathrm{ka}$ (Ref. ES 27) (Galván et al. 2014).

\section{Abric del Pastor}

Abric del Pastor is a small rock shelter $\left(60 \mathrm{~m}^{2}\right)$ located on the right side of a gorge at 730 masl in the Mariola Mountains of Alcoi, Alicante. The area is mountainous, with numerous valleys and natural corridors, and rich in siliceous resources. The rock shelter structure is made up of a limestone cobble conglomerate. It is an eroded karstic tube within a larger karstic network linked to the phreatic activity of the nearby Serpis River. Electron spin resonance (ESR) dates obtained from teeth recovered in Stratigraphic Unit (S.U.) IVb (48 ka $\pm 5 \mathrm{ka})$ and S.U. VI (62 ka $\pm 10 / 9 \mathrm{ka})$, as well as an OSL date from a quartz grain recovered in S.U. IVd (63 ka $\pm 5 \mathrm{ka})$, chronologically place Neanderthal activity at the site within MIS 4 and the early stages of MIS 3 (Machado et al. 2013; Hernández et al. 2014; Connolly et al. 2019; Mallol et al. 2019).

The chronology of Palaeolithic sites from the central Iberian Mediterranean region indicates Neanderthal settlements from MIS 9-8, documented in Bolomor phase I, to (most recently) MIS 3. With the arrival of the last interglacial, the number of sites increases. The most recent dates for the end of the Middle Palaeolithic (between $38 \mathrm{ka}$ and $45 \mathrm{ka}$ ) are those of Cova Beneito, Quebrada and El Salt (Iturbe et al. 1993; Villaverde et al. 2008; Galván et al. 2014).

\section{Materials and Methods}

The choice of sites was based on the availability of information regarding lithic industry, faunal assemblages, taphonomy and use of space. We focus on the levels in which we have enough information about these aspects to outline their main characteristics and homogenise the data that allow us to compare them. We do not take into account other sites and/or levels in which, despite the existence of good preliminary information, the data do not allow more in-depth research, such as Levels XI, IX and VIII from El Salt, where we lack lithics and faunal information; Levels I to III, V and XIII from Bolomor, and Levels II, III and V from Quebrada and Pastor, where we do not have detailed spatial or faunal data. Of the sites described above and those that serve as a comparative framework in the Mediterranean Iberian Peninsula, information from Abrigo de la Quebrada and Cova Negra results from our own analysis and comprises either first-hand or revised data (Villaverde et al. 1996, 2009, 2017; Eixea et al. 2011; Eixea 2015, among others).

For each assemblage, we start with a comprehensive and detailed analysis of the following data:

1. Lithic assemblages were studied by reconstructing the reduction sequences for each large class of raw material unit (Roebroeks 1988). The sourcing of raw material employed geological surveys along with macroscopic and microscopic analyses. The technical processes identified have been described according to classical 
approaches, with the aim of reconstructing knapping, shaping and retouching modes (Geneste 1988; Boëda et al. 1990; Boëda 1994; Geneste et al. 1997). Reduction sequences have been identified using a techno-economic approach (Jaubert and Farizy 1995; Jaubert and Mourre 1996; Geneste et al. 1997). We highlighted the variability of strategies in management of the resources, as well as the constraints imposed by raw materials on the technological aspects and/or on the coexistence of different knapping methods. The refitting analysis allowed us to identify the temporal relations between knapping events. Moreover, refits provided information about site and assemblage formation processes. Refits were often used to demonstrate that different accumulations were contemporaneous, although it now seems clear that the simple connection between two artefacts is not enough to allow us to argue that two activity areas were formed during the same occupation episode (Bordes 1980; Larson and Ingbar 1992; Vaquero 2008; Vaquero et al. 2015, 2017).

2. For each faunal assemblage, we obtained the following data through different studies carried out by several authors (Martínez Valle 1996, 2009; Blasco 2011; Blasco and Fernández Peris 2012; Sanchis et al. 2013, 2015a; Salazar-García et al. 2013; Machado et al. 2013; Pérez 2014, 2015; Machado and Pérez 2016; Martínez Valle et al. 2016; Villaverde et al. 2017; Pérez et al. 2017; Real et al. 2020). These data are collected in Table 3 and include levels studied, main taxa, number of taxa, NISP, total faunal remains, percentage of identification, anatomical representation, NISP/percentage of carnivores, number of carnivores, as well as taphonomic information regarding carnivore's marks (pits, punctures, scores, furrows, notches and corrosion by digestion) and percentage of anthropic marks (cut-marks, percussion marks and burnt marks).

3. At the microspatial level, the total excavated area $\left(\mathrm{m}^{2}\right)$ and the thickness $(\mathrm{cm})$ of each level are considered in order to obtain the number of pieces per $\mathrm{m}^{3}$. We retrieved the density of materials taking into consideration the length and width of the surface and the thickness of each level. Attention has been also paid to analysis of the spatial structure, looking at the distribution of remains on the excavated surface, taking into consideration, in particular, the association of these remains with the hearths, which are usually the centre of the domestic areas (Stapert 1990; Vaquero and Pastó 2001). The form of the combustion structures in Palaeolithic archaeological studies has been described according to typological features (Perlès 1976; Beeching and Gascó 1989) as flat, concave, and cuvettes. Combustion structures may or may not be delimited by stones. Flat structures occur in carbonaceous areas of all dimensions, whereas concave shapes are limited to middle-sized carbonaceous areas. As Kent (1987) pointed out, the distribution of the combustion structures and scatters of archaeological remains indicate that there are at least three general types of spatial unit located in the internal, central and external topographical zones. The spatial patterning of archaeological items such as combustion structures, blocks and slabs and other natural features, as well as the distances to the rock shelter wall or the drip line, might be a fundamental requisite for site structure research. Combustion structures in extensive excavations are scarce and may provide empirical evidence for the organisational properties of the archaeological record (Binford 1982, 1983). This empirical combination of structures (cultural and topographical) and accumulations of lithics and faunal remains provides two worthwhile 
preliminary topics of discussion: (1) the archaeological visibility of spatial units and activity episodes; and (2) the analogies with spatial patterns and activity areas of modern foragers as a guideline for site structure research. The spatial patterning and temporal analysis of activity episodes will be revisited and further developed in subsequent chapters.

\section{Results}

\section{Raw Material Procurement and Technological Behaviours}

The main raw material exploited is flint, which accounts for more than $90 \%$ of the remains. The only exception is Level XII of Bolomor (MIS 6), in which the limestone has a dominant role, as can be seen in the strong presence of colluvial cobbles in the moments of more rigorous pulsation, indicating the remoteness of the sea and an immediate or short catchment in the contiguous hillside deposits (Fernández Peris et al. 2008). Flint catchment areas are local $(5-10 \mathrm{~km})$ and semi-local (10-20 km), focused on calcareous Mesozoic territories and Neogene deposits that allow a wide territorial distribution although with unequal origin, quality and petrological variety. In many cases, humans exploit secondary deposits that are related to extensive erosive and depositional geological cycles that occur in multiple sedimentary environments (alluvial, marine or colluvial deposits, among others). The provenance of long-distance flint is attested (Table 2). In Quebrada, allochthonous types from the southern part of the Valencian Country (Serreta and Mariola flint: $120 \mathrm{~km}$ ) are documented throughout the sequence, especially at basal Levels (VII and VIII, MIS 5), with quantifications that oscillate around 7-9\% of the assemblage. The same happens in Level X of El Salt (MIS 3) and Pastor IV (MIS 4), where some cores have been found together with configured elements but with the difference that the quantifications are much lower $(<3 \%)$ (Molina 2016). The available data seem to point towards a mobility pattern that relates the interior zones to the coast through the natural corridors of the Turia, the Plana de Utiel and the Magro. These flow into the great plain of Valencia, which allows a much greater mobility to the north and, especially to the south, where they would come into contact with the deposits of the nucleus of La Safor and El Comtat (Cova Negra or Cova del Bolomor) and Alcoi valleys (Cova Beneito, Abric del Pastor and El Salt).

Local and semi-local raw materials, quartzite, limestones and quartz, which make up the range of lithologies with flint, are almost always knapped inside the sites, except for some larger unretouched flakes that are brought from the outside. These are used as a tool or as a core on flake, which indicates in some cases an interruption in the operative chains from the same outcrops. Long-distance flint usually arrives at the site as retouched tools or as cores. These items do not represent more than 5\% of the whole assemblage. For example, in Quebrada Level IV the Serreta flint comes through small-format cores that have already been exploited, and some scrapers with resharpening edges are also attested. There are two main types of stone tool production: first, the discoid method, which represents the majority (about $80 \%$ of the supports of all sets), is determined based 


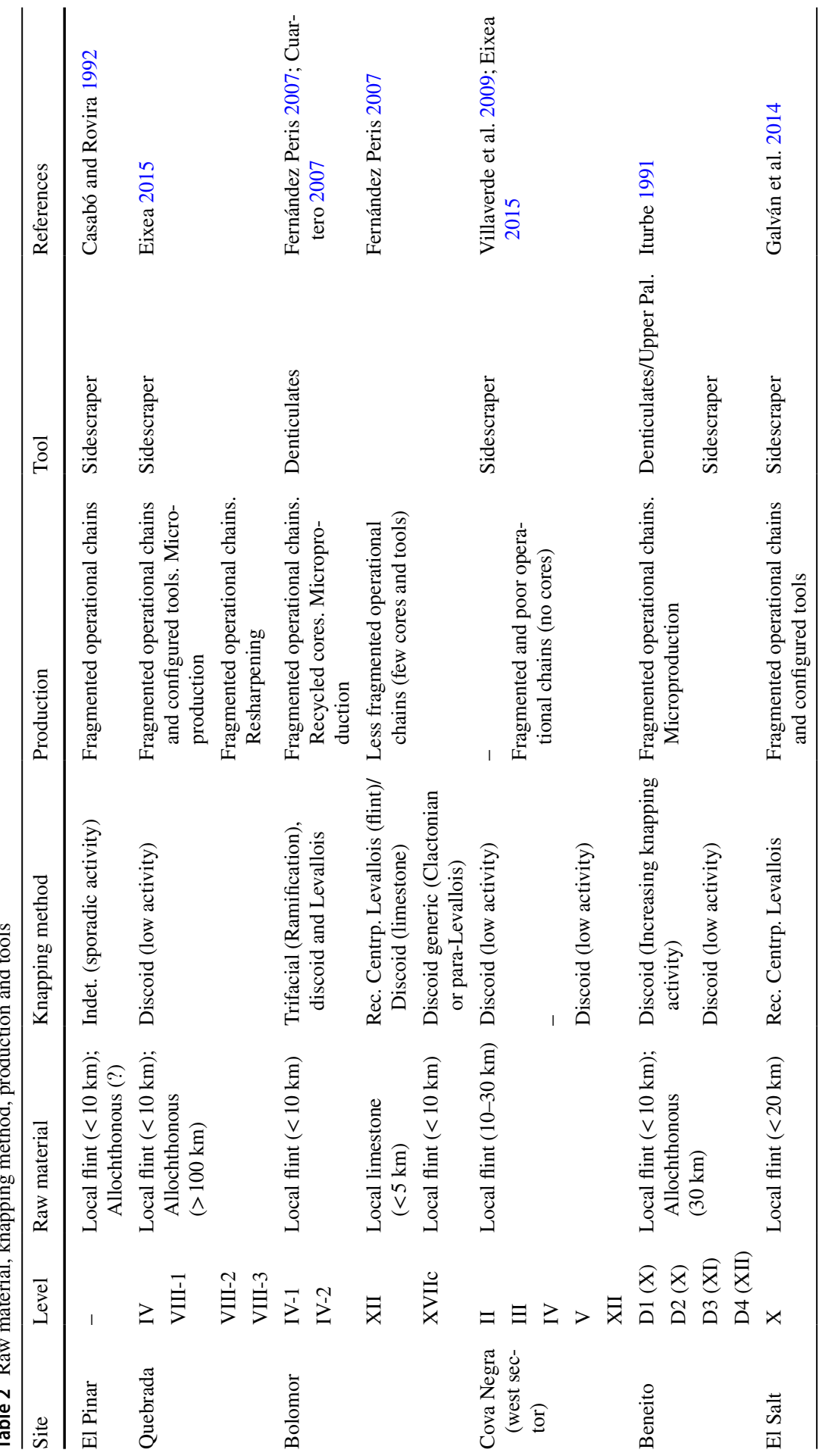




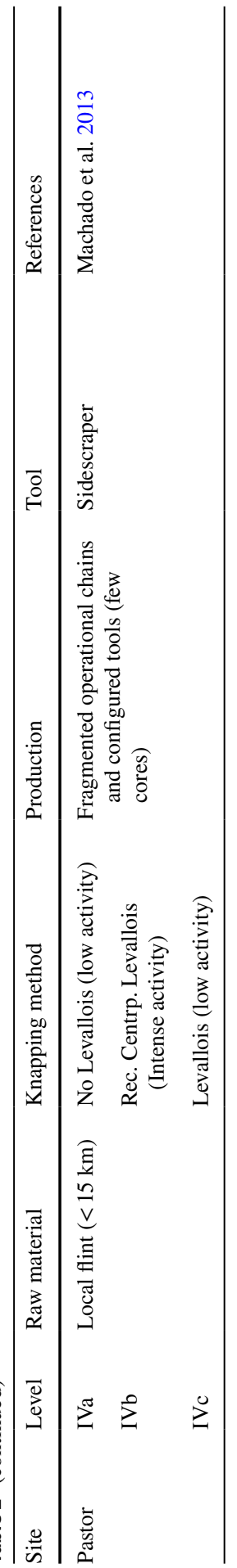

照 Springer 
on its unifacial and/or bifacial management and does not present significant differences between them (Cova Negra Levels II, III and XII, Bolomor XVIIc and Beneito X to XII). Cobbles of varied morphologies usually oval and globular, are exploited, with no previous preparation. After the first removals, the peeling flakes of the nodule are included within the retouched material. The other method is the Levallois, which is secondary in most of the assemblages, except at El Salt (X) and Pastor (IVb and IVc). This is applied not only to flint but also to other rocks such as quartzite and limestone, indicating a highly versatile knapping system (Eixea et al. 2016). This suggests that decisions related to the knapping method are not merely a reflection of the local availability of raw materials but can be influenced by other factors and variations in, for instance, the duration of occupations, number of individuals who occupy the site, tasks for which the material is used, and settlement functionality. Thus, the variety of raw materials employed is indicative of the plasticity of the Neanderthal groups in the choice of knapping systems. This suggests that these decisions are made more from a sense of knowhow and accumulated experience over generations than from the influence of technological traditions learned and repeated in an unreflective way. This pattern coincides with what may be deduced in consideration of the reflexivity and versatility of the culturally-mediated adaptation of developed lithic production (Bourguignon et al. 2004; Rios et al. 2014; Romagnoli et al. 2018). Significant features include: the change from one method to another in the management of the same core-depending on the platform types needed for the envisaged task(s) (Lenoir and Turq 1995; Jaubert and Farizy 1995; Slimak 1998; Terradas 2003; Mourre 2003); flake- and core-recycling (Mora et al. 2004; Hiscock 2009; Barkai et al. 2010; Vaquero 2011; Thiébaut et al. 2012; Vaquero et al. 2015; Baena et al. 2017); and the directed production of small items for reasons unconnected to any upper size limits in the raw material itself (Bordes 1981; Goren Inbar 1988; Koumouzelis et al. 2001; Kuhn and Elston 2002; Moncel 2003; Mora et al. 2004; Dibble and Mc Pherron 2006; Turq et al. 2008; Moles and Boutié 2009; Rios 2010; Villaverde et al. 2012). The main modality of the Levallois method is the centripetal recurrent, which usually represents more than $90 \%$ of the remains, with a much smaller representation of the preferential modality. Uni- and bipolar management is marginal $(<5 \%)$, and is reflected in the poorly laminar morphology of the supports. The reduction sequences are characterised by the first phases in which the preparation of the core is oriented to obtain the largest support, Levallois preferential flake sensu stricto, to later change the production towards the obtaining of recurrent formats that can be divided into two types: typical recurrent ones, with symmetrical, well-organised removals on the surface of the piece and faceted striking platforms; and atypical recurrent, with similar characteristics but with the difference that they frequently present overflowing elements (presence of lateral cortical elements, méplat, etc.), more dissymmetric formats and less prepared striking platform (flat and dihedral domain). In both the discoid and Levallois methods, flakes are produced in a long series that continues until the maximum amount that can be extracted from the blank is reached. This intense management of the core volumes leads to the acquisition of some products of small dimensions, below $2 \mathrm{~cm}$, that are frequently transformed 
by retouching (Fernández Peris 2007; Galván et al. 2009). In addition, there are other, recycled schemes for flake tools made on cores that approach a trifacial conception, although with certain nuances (Cuartero 2007).

Finally, tools are dominated by side-scrapers, while the representation of large tools is low, with the exception of some macrolithic tools of the non-Acheulean type at Bolomor (Fernández Peris 2007) and some Acheulean techno-typological event, or at least the association of bifaces and tools belonging to an older typology, such as limaces and Tayac points, at Cova Negra lower levels (Eixea et al. 2020). Normally, one edge is retouched (simple and transverse) against two or more configured edges (convergents, doubles or déjéte). For example, in all Quebrada levels more than $40 \%$ of the tools are simple side-scrapers, and there is a concomitantly low diversity in notches and denticulates, as well as in Upper Palaeolithic elements, which are rare (5-10\%). The same situation obtains at El Pinar (MIS 5-4), Cova Negra, Pastor and El Salt, but is contrasted at Bolomor (IV, XII and XVIIc) where what predominates is the group of denticulates and notched pieces, which are usually lateral, with marked denticulation and some with pronounced thorns; the average size is usually smaller than with side-scrapers, just as the asymmetry is more marked. Something similar happens in Beneito, where there is an internal evolution from Level XII onward. In Levels XI and X side-scrapers decrease and notches and denticulates increase, eventually giving way to a final moment in which side-scrapers-which lose polymorphism and are dominated by simple types-represent no more than $25 \%$ of the industry. Finally, the Upper Palaeolithic group appears in all its variety, displaying a predominance of naturally backed knives. The laminar index also increases, and the faceted values on the percussion platforms decrease (Iturbe et al. 1993).

\section{Faunal Data}

The central area of Mediterranean Iberia has a significant tradition of studies of Middle Palaeolithic faunal assemblages. The more focused paleontological works (for example, Sarrión 1990, or even Pérez Ripoll 1977) are complemented by others with an archaeozoological or taphonomic focus (Pérez Ripoll 1992; Villaverde and Martínez Valle 1992; Martínez Valle 1996, 2009; Villaverde et al. 1996; Sanchis 2010, 2012; Blasco 2011; Blasco and Fernández Peris 2012; Pérez 2014; Real et al. 2020). For this reason, if we look at the data in Table 3, we will see that the sample studied is smaller than we would like, with different methodological approaches and heterogeneous development of taphonomic aspects, key in determining the origin of the accumulations. For this reason, it is sometimes difficult to compare information between sites and to obtain an overview of the role of fauna in the subsistence of the Neanderthal groups that occupied the territory of present-day Valencia.

The Iberian Peninsula is a marginal geographic area of the European continent that acted as a refuge for diverse species during the most rigorous phases of the Pleistocene (O'Regan 2008). This is the case for the leopard, which disappears in the French territory before the LGM, while in the Iberian Peninsula there are records during this phase, the Tardiglacial and even the initial Holocene (Sauqué 


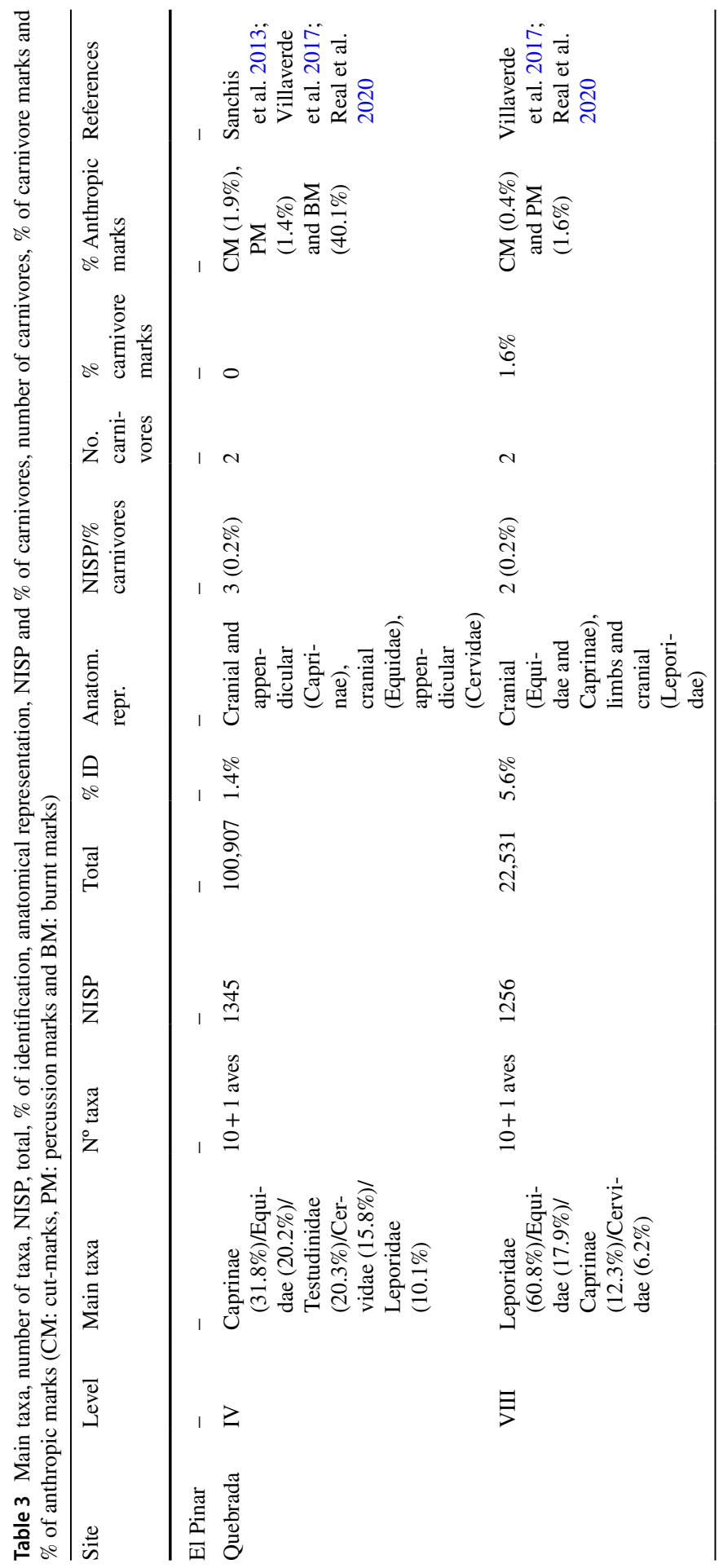




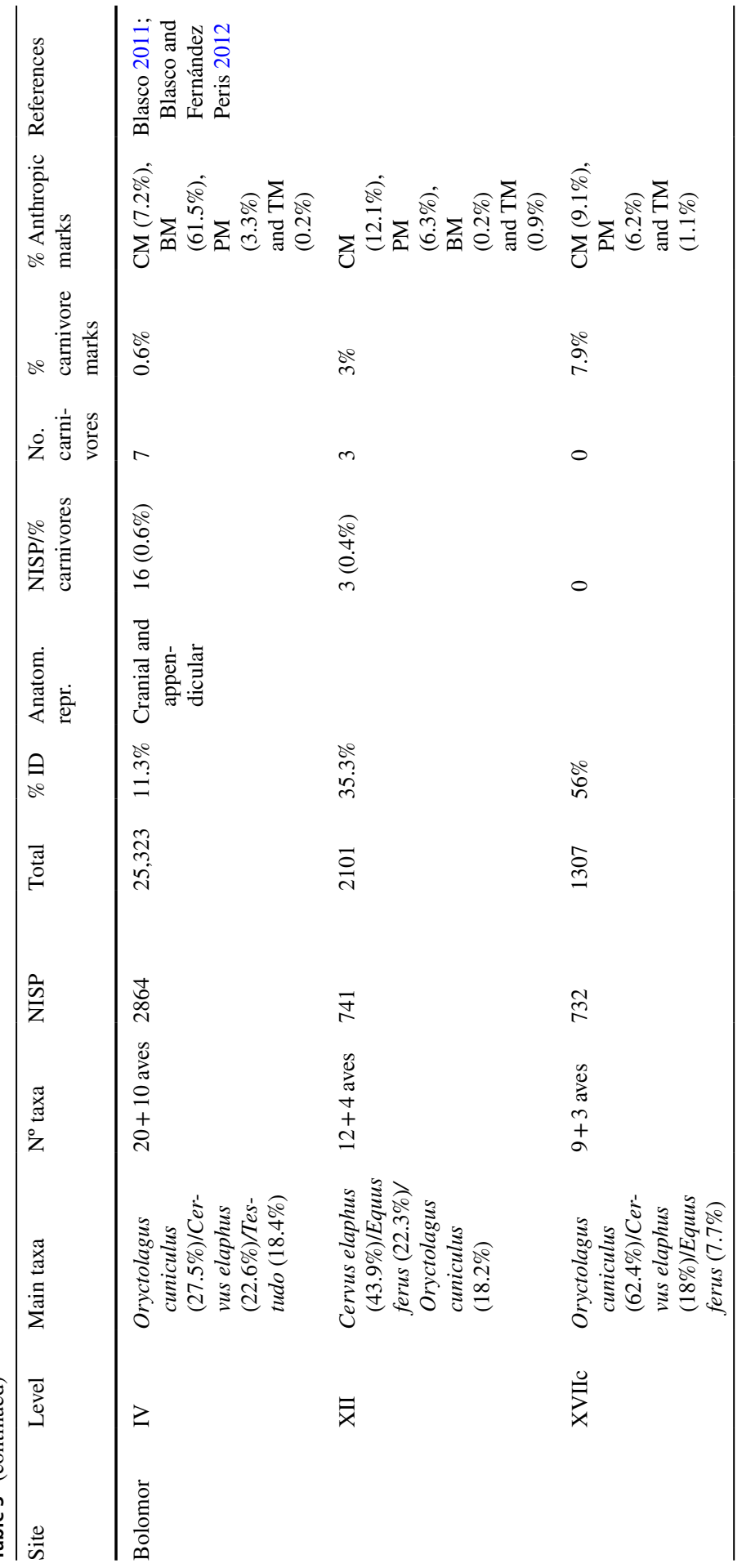




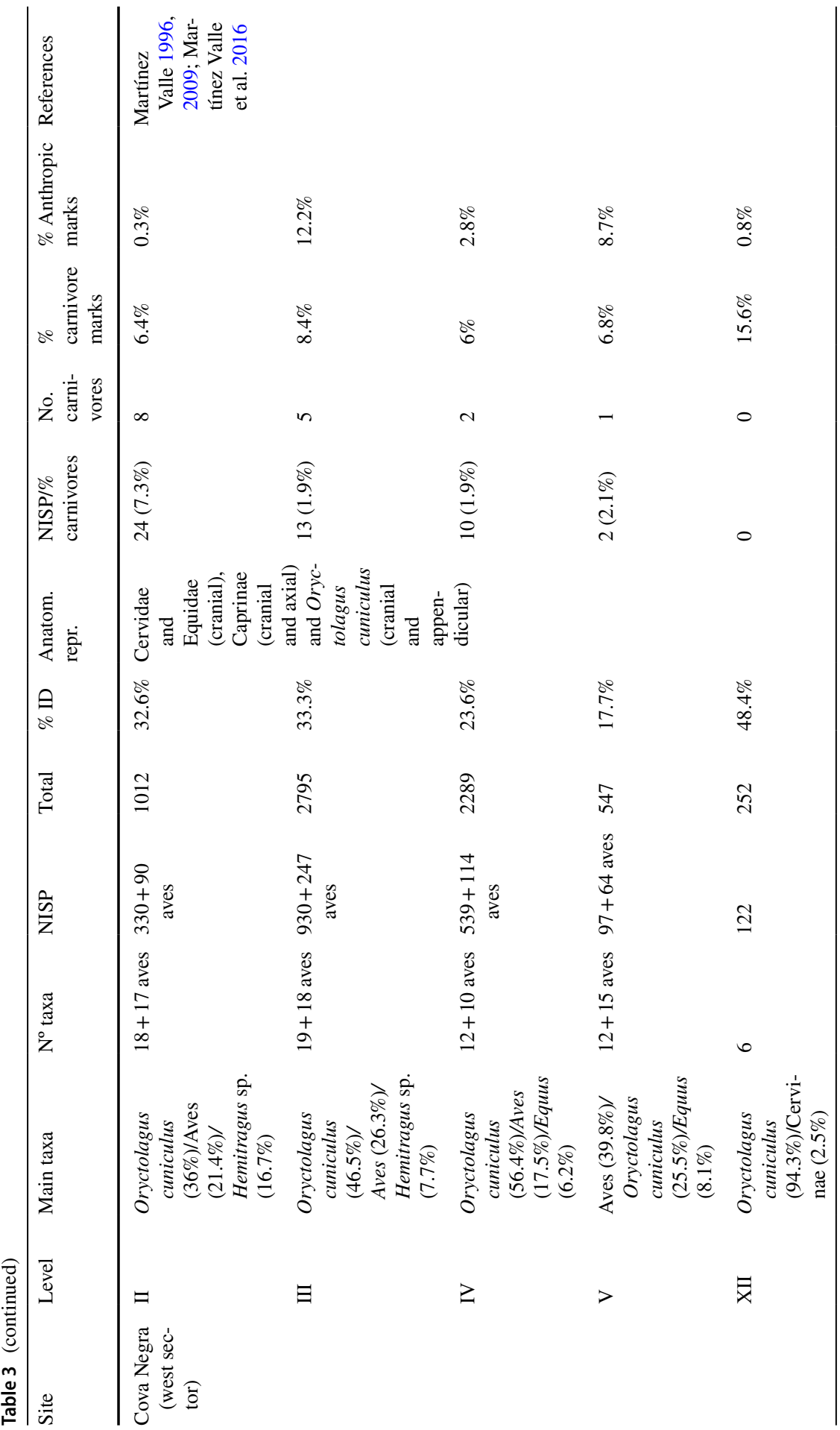




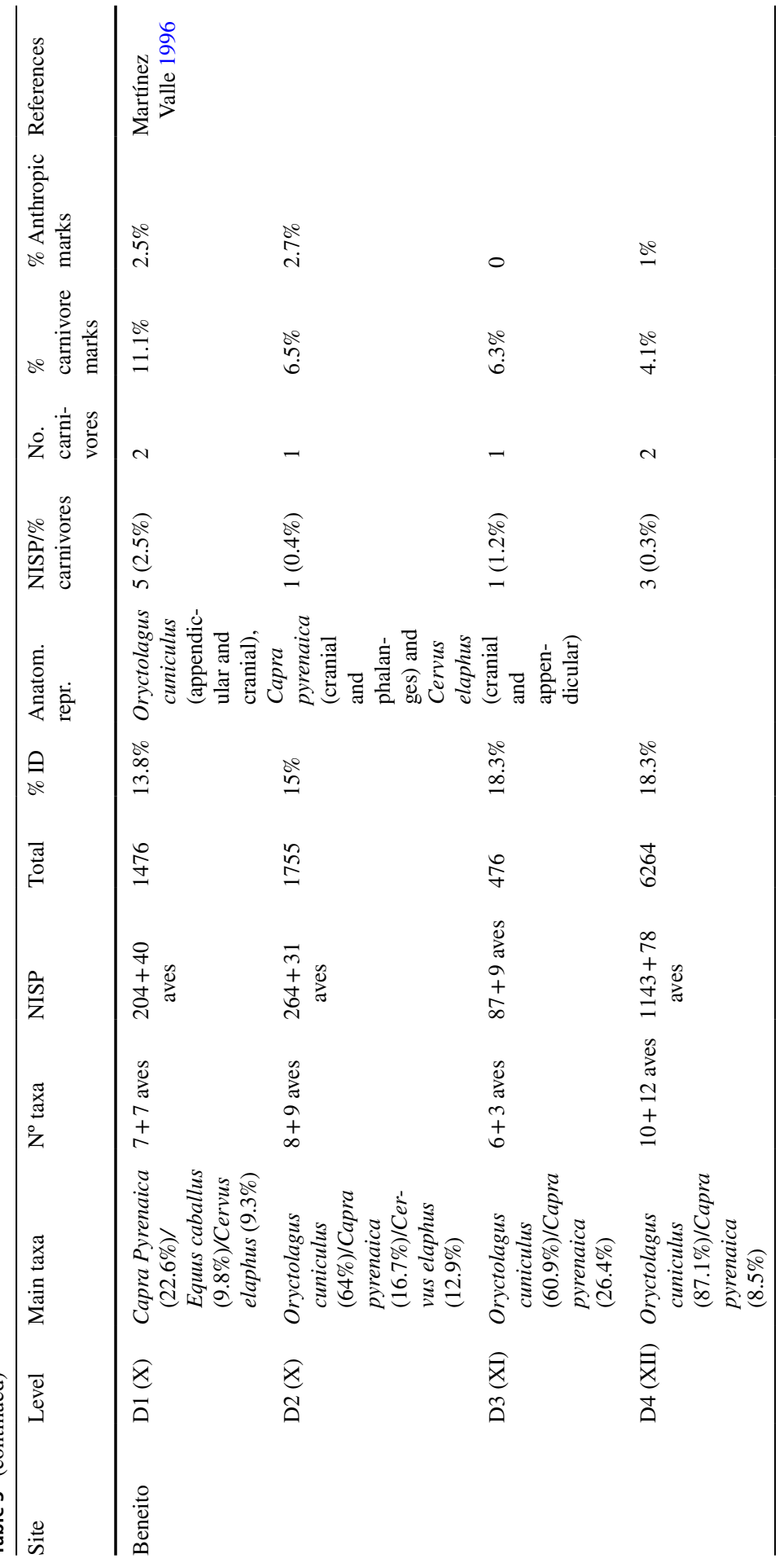




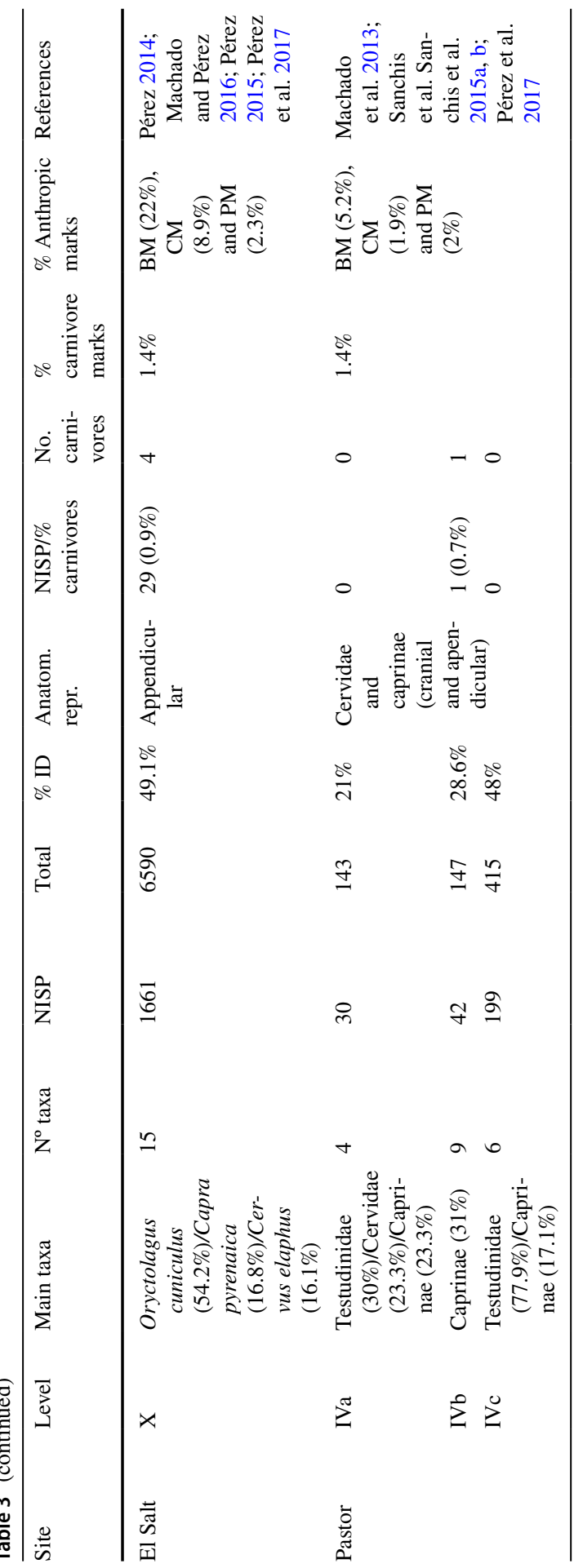


and Cuenca-Bescós 2013; Sanchis et al. 2015b). Within this area differences are also observed, for example in the distribution of cold fauna taxa. Species such as the woolly rhinoceros or the reindeer do not appear in the Pleistocene caves of the Valencian area. In spite of these differences, one of the characteristics of the faunal collections from the Iberian Middle Palaeolithic are their taxonomic diversity. Notwithstanding the chronological differences between the sites, their location and the environmental conditions, the faunal assemblages can be considered diversified (Blasco 2011; Salazar-García et al. 2013; Fiorenza et al. 2015).

The most prominent taxa of the Middle Palaeolithic Valencian deposits are discussed here and summarised in Table 3. In general, two large groups can be identified: one formed by ungulates of medium and large size corresponding to Bovidae-Caprinae, Cervidae and Equidae; the other by small prey, with a predominance of rabbit and more variable presence of tortoises, depending on the environmental conditions. The ungulates and rabbit can be regarded as eurythermal species present in both rigorous and temperate moments, while the tortoise is more abundant in temperate and humid phases. Rabbit (Oryctolagus cuniculus) is the predominant species on many levels: Quebrada VIII, Bolomor IV, Bolomor XVIIc, Cova Negra II, III, IV and XII, Beneito X, XI and XII and El Salt X. The Mediterranean tortoise (Testudo hermanni) predominates in Pastor IV, where it is the most important species, and in Quebrada IV and Bolomor IV it is the third species in importance. Birds reach relevant quantifications in all levels of Cova Negra. With respect to ungulates, two main genera of caprini corresponding to tahr (Hemitragus bonali/cedrensis) and Iberian ibex (Capra pyrenaica) have been determined. They are species adapted to the abrupt reliefs of high hills and are present in several Valencian deposits. Tahr appears in the Middle and early Upper Pleistocene contexts of Bolomor and Cova Negra, while the Iberian ibex is shown in more recent Late Pleistocene contexts such as Quebrada, Beneito, El Salt and Abric Pastor. Caprini stand out in Quebrada $\mathrm{IV}$, Pastor IVb, and Beneito X, although if we disregard the small prey, especially the rabbit, they would be the most important group in Pastor IVa and c, Beneito X, $\mathrm{XI}$ and XII and El Salt X. The most represented cervids in the sets are red deer (Cervus elaphus) and fallow deer (Dama sp.). The cervids are the most prominent group in Bolomor XII, and if we discount the rabbit, also in Bolomor IV and XVIIc; in the same way, if the tortoises of Pastor IVa are not taken into account, the cervids would predominate. At other levels, as in Beneito $\mathrm{X}$ and El Salt $\mathrm{X}$ their values are behind the caprini. Equidae present include the horse (Equus ferus). Aside from the rabbit, they are the first group in Quebrada VIII, while they are the second in Quebrada IV behind the Iberian ibex, and in Bolomor XII behind the cervids. At the other levels their representation is more modest (see references and representation values in Table 3).

The incidence of carnivores in faunal assemblages seems much lower than that documented for the Middle Palaeolithic in other areas of the Iberian Peninsula. Some authors advocate a reduced role for carnivores as agents of accumulation and alteration of bone remains in deposits such as Bolomor (Fernández Peris 2004). This could be true of the rest of the Valencian deposits during this phase, except for Cova Negra and Beneito, where the remains of ungulates and leporids present a greater number of modifications attributable to carnivores and especially birds of prey than 
to any human action, although a recent detailed review of the whole of Level IIIb at Cova Negra identifies a predominantly anthropic contribution (Martínez Valle et al. 2016). The prominent role of mammalian carnivores in Cova Negra seems to be confirmed by the presence of hyena coprolites at basal levels. Likewise, in both Cova Negra and Beneito the number of carnivore taxa represented is higher than in the rest of the deposits. In any case, it should be taken into account that the sets of these two deposits should be reviewed through a major general taphonomic approach (Martínez Valle 1996). In relation to the presence of carnivores during the Middle and Upper Pleistocene, the information we have for the Mediterranean area seems to indicate a lower incidence than in other areas of the Iberian Peninsula such as the Cantabrian or central zone (Sala et al. 2012; Sanchis et al. 2019). In the Mediterranean area there is no record of the cave bear (Villaluenga 2009), and references to hyena and lion presence in the caverns are very scarce. In the Valencian region during the Middle Palaeolithic and the beginning of the Upper Palaeolithic, the action of hyenas in the caves was less marked than in the Cantabrian and other peninsular areas, while the role of other carnivores could be greater than hitherto believed, with cases of leopard-created accumulations of fauna in caves during phases of human absence having recently been documented in several peninsular sites (Sauqué and Sanchis 2017; Sauqué et al. 2018; Sanchis et al. 2019).

In the majority of sites, anthropic modifications-mainly cut-marks and percussion impacts - are present at higher percentages than those produced by carnivores, so the diversity of taxa represented at each level can be considered as representative of anthropic predation. The diet of the Neanderthal groups in these deposits was based on medium and large ungulates, whereas the acquisition of small prey, such as the rabbit, is more prominent only in some levels of Bolomor. However, in the Bolomor levels with predominantly anthropic rabbit accumulations (Ia, IV, XI or $\mathrm{XII}$ ), the representation values of this species are lower than in the Levels (XV and XVIIa) where the rabbit is supplied by birds of prey and carnivores (see Table 1 in Salazar-García et al. 2013). This indicates that although consumption of small prey by the Neanderthals is evidenced at some levels of this deposit, it never attains the significance seen in the assemblages of the regional Upper Palaeolithic (Pérez Ripoll and Villaverde 2015; Sanchis et al. 2016). In the other deposits, rabbit accumulations are predominantly due to the action of birds of prey and small carnivores. In the deposits where the contributions are mainly of anthropic origin, we observed differences in the anatomical representation according to the size of prey. For example, in Quebrada IV, Iberian ibex is represented by both cranial and appendicular remains, whereas the equids are represented mainly by cranial remains. In Bolomor and Pastor the ungulates are represented by cranial and appendicular fragments. In Cova Negra and Beneito, non-anthropic Iberian ibex are documented by cranial, axial and phalanx remains. In small prey sets there are no differences according to the anthropic and non-anthropic levels because these prey are transported whole to the sites.

Although the subsistence of human groups is based on the hunting of ungulates there are few data on the use of certain carnivores (dangerous taxa) during the Middle Palaeolithic. The leopard and dhole remains with cut-marks identified in Cova Negra show the existence of interaction between carnivores and humans, possibly 
due to competition for the use of caves and access to prey (Pérez Ripoll et al. 2010; Sanchis et al. 2015b). This interaction has also been determined in Cova Negra, with the occurrence of dental marks of a felid on an infant Neanderthal cranial fragment, supposedly produced during an attack (Camarós et al. 2016).

In the Upper Palaeolithic sites from the Valencian region, animal-based subsistence is focused on specialised hunting of Iberian ibex or red deer depending on the location of the sites themselves, accompanied by a high percentage of rabbit remains. In contrast, the data presented for the Middle Palaeolithic seem to be related to a more opportunistic and generalised behaviour, where the resources present in the environment are exploited flexibly through hunting and also scavenging. The study of fauna, isotopes and Neanderthal teeth reveals the importance of terrestrial meat, although we could consider their diet omnivorous given the seasonal consumption of vegetables (Salazar-García et al. 2013; Fiorenza et al. 2015). This model has traditionally been linked to the mobility patterns developed by human groups, with mobility ratios higher during the Middle Palaeolithic and lower during the Upper Palaeolithic (Aura et al. 2002; Villaverde et al. 1996, 2012).

\section{Spatial Patterning}

Analyses of intrasite spatial patterns have focused on the possibility of establishing a high-resolution dissection of the diachronic components that made up the different occupation units. This approach is based on distribution analysis of the different raw material units (Machado et al. 2013), the study of hearths and the vertical projection of the materials (Sañudo and Fernández Peris 2007; Marrero et al. 2011). However, refitting studies have been less systematically conducted with respect to faunal remains than to stone tool assemblages (Eixea et al. 2011), in line with the work carried out, for example, in Catalan sites like the Abric Romaní (Vaquero et al. 2007, 2012, 2017; Rosell et al. 2012; Bargalló et al. 2016) (Table 4).

In the Bolomor sequence, Level IV has been the archaeological unit analysed in the greatest detail from a spatial point of view. The excavated area is $14 \mathrm{~m}^{2}$, more than three thousand elements have been recovered, and the density is higher than a thousand pieces per $\mathrm{m}^{3}$. This level has been divided into two sub-units, CBIV-1 and CBIV-2. The first shows different episodes of activity, identified from the accumulations of small elements. These indicate the location of activity areas, where the remains are deposited on the spot. The area adjacent to the activity area contains larger materials with different characteristics, which may correspond to a discard pattern. The second unit presents a different and more complex occupation pattern, manifested by different structural elements that articulate the space-among them the host structure itself; the hearths $(n=3)$, which are simple, flat and around 0.5-1 $\mathrm{m}$ in diameter; the accumulations of blocks; and the latent structures. The internal organisation is conditioned by the delineation of the drip line, creating a differentiation between the sheltered area and the external area, as seen in CBIV-1 (Sañudo and Fernández Peris 2007). In short, as has been pointed out, the behavioural pattern is based on the organisation of space around domestic units in which a wide range of daily activities are developed, including food preparation, 


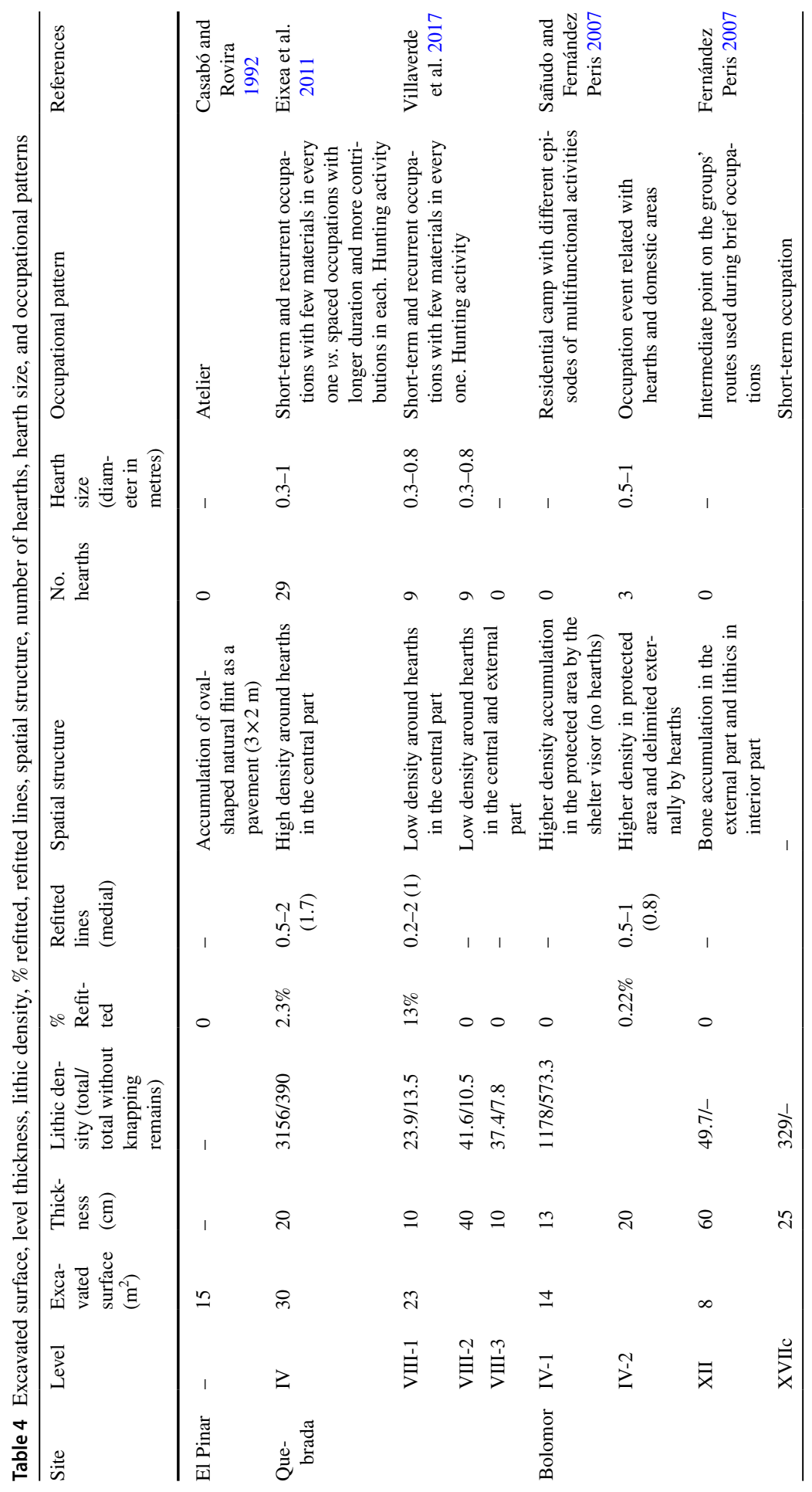




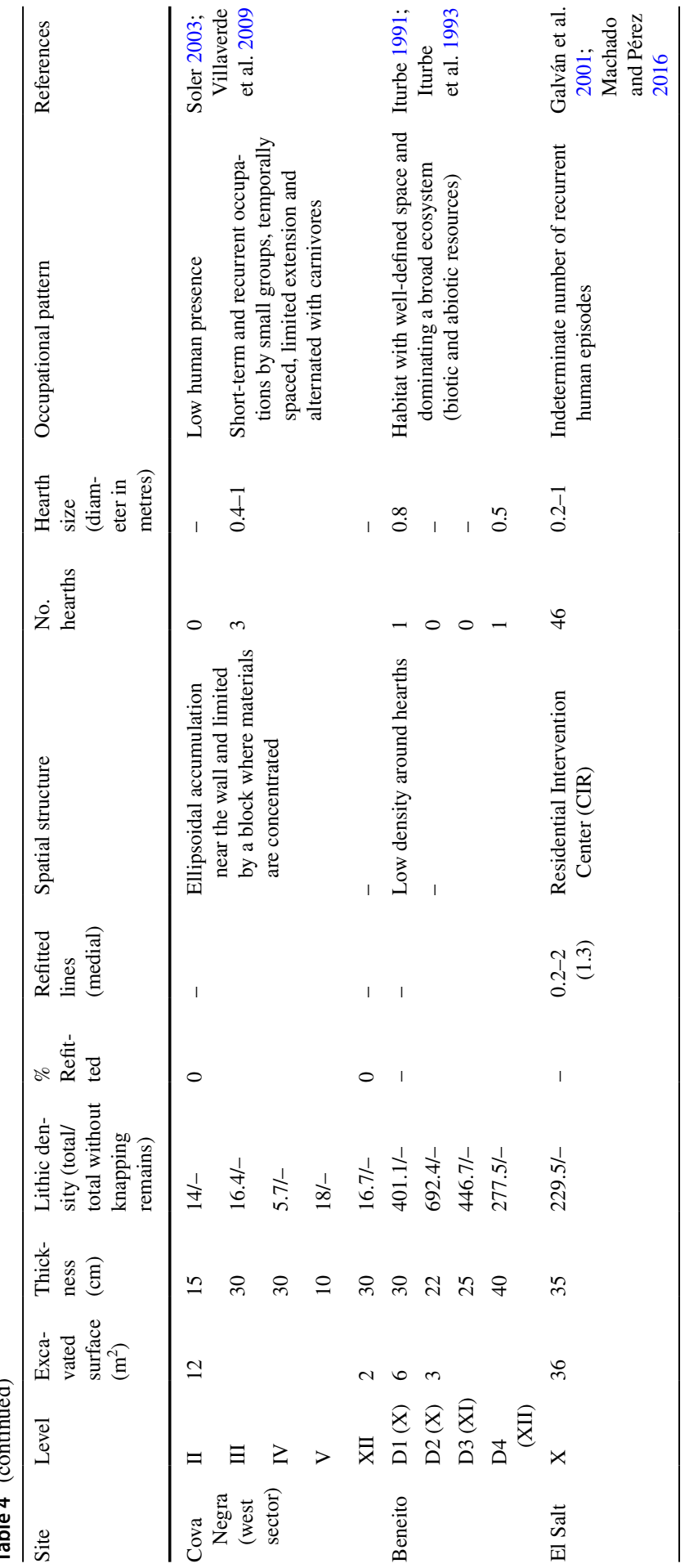




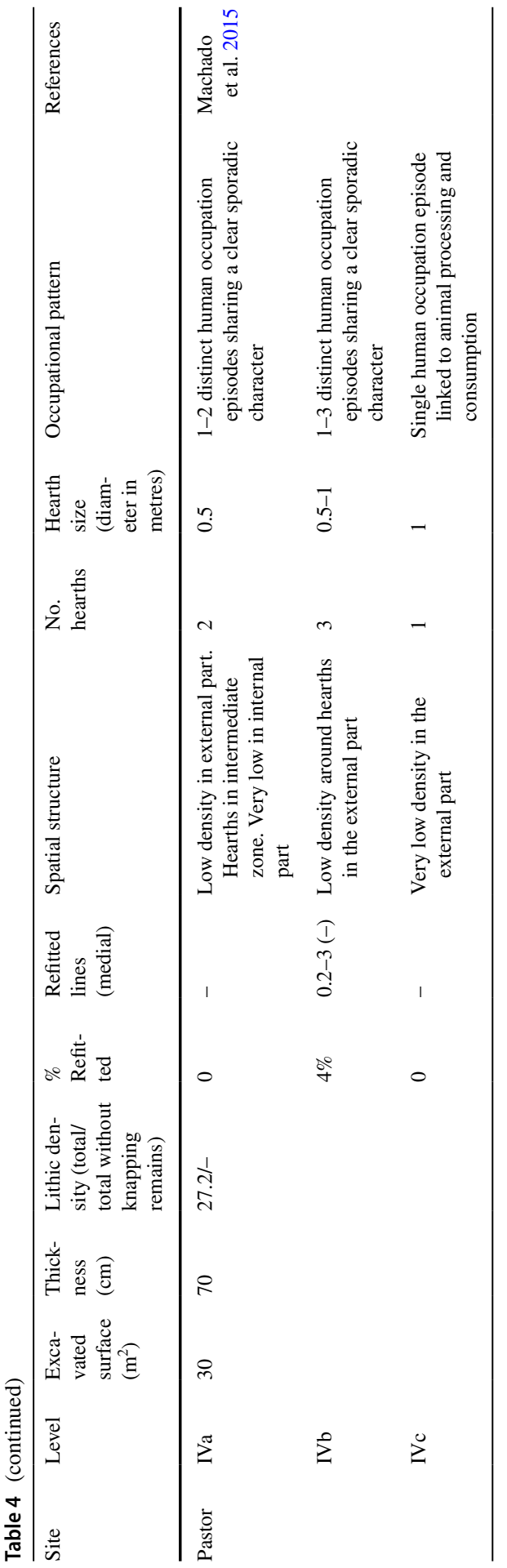


consumption and production, as well as the use of tools, and social relations between the group members (Fernández Peris 2007; Sañudo and Fernández Peris 2007). Diachronically, Levels XII (MIS 6) and XVIIc (MIS 9-8) present significant differences in comparison to Level IV. These lower units are between 60 and $25 \mathrm{~cm}$ thick and their excavated surface is smaller $\left(8 \mathrm{~m}^{2}\right)$, providing 175 and 329 lithic elements, respectively. There are neither combustion structures nor refits, and the density is much lower than at Level IV (from approximately a thousand elements per $\mathrm{m}^{3}$ to 49.7 and 329). In Level XII up to 7 archeostratigraphic units have been identified, all of them separated by episodes of block falls and sterile beds. Some of these units present bone remains altered by carnivores, which indicate moments of abandonment of the cave (Sañudo et al. 2015). The bone and lithic distributions indicate a greater number and wider distribution of bone remains in the exterior area and a concentration of lithic remains in the interior. According to Fernández Peris (2007), the level reveals rigorous climatic conditions, with a theoretical modification in the coastline, which suffered a strong regression. These changes could have influenced migratory circuits and occupations. The preferential provisioning of limestone, which is the dominant raw material in these levels, implies that the supply area was the immediate vicinity of the site, where limestone is abundant. In addition, there is a high percentage of knapping elements (cores and percussors), while non-configured elements and small products are absent. This points to the notion that the initial stages of the reduction sequences were dominant. The lithic production sequences are less fragmented than at other levels, which may be due to a low mobility of objects between different occupation places. In this sense, the volume and transformation of the archaeological materials suggests that Bolomor XII was possibly a place of passage with very brief occupations, different from other levels that present longer occupations and a greater complexity in their activities.

Level IV of the Abric del Pastor is $70 \mathrm{~cm}$ thick and has been subdivided into three lithostratigraphic units (IVa, IVb and IVc), with an excavated surface of $30 \mathrm{~m}^{2}$. According to Marrero et al. (2011) and Machado et al. (2013), the spatial dynamics are conditioned by the reoccupation of the rock shelter, with similar organisational patterns, especially between IVb and IVc. In fact, there is no great difference between these two stratigraphic units in relation to spatial organisation, which is characterised by the central role played by the combustion structures ( 3 in IVb and 1 in IVc), around which most activities were carried out. Hearths appear as mere circular lenses of thermally altered sands, with dimensions ranging from 0.5 to $1 \mathrm{~m}$ in diameter. At both units, the accumulations indicate few production and consumption events. In the most evident cases, the organisation of the hearth-related activity areas shows a dispersion of the vestiges that occupy only one side of the combustion structure, while the opposite side exhibits a lower density of remains or is entirely empty. In both units IVb and IVc, a semi-circular distribution of remains around the respective combustion structures is therefore observed, similar to those described by Binford (1978). On the other hand, the distribution of micro-remains reflects the same organisational scheme that is derived from the study of macro-remains. At times, it is necessary to take into account that a possible vertical movement of the items, related to sedimentary dynamics and diverse taphonomic processes, could have changed the original spatial structure. In short, the thermal impacts of 
successive hearths reflect reiteration in the spatial organisation pattern. The areas closest to the rear of the rock shelter barely contain any archaeological material. They are empty spaces, covering an area of about $6 \mathrm{~m}^{2}$, which could be related to possible use as a 'sleeping zone', following ethno-archaeological criteria such as the existence of a heat source in the vicinity and the protection of the rock shelter wall (Binford 1982; Galanidou 2000; Vallverdú et al. 2010). In any case, they are sporadic, low-intensity occupations characterised by a little repetition in the use of the same space to perform successive activities across a broad space-time continuum, which facilitates the work of identifying the areas and possible events of knapping or food consumption (Marrero et al. 2011, Machado et al. 2013, 2015; Mallol et al. 2019) (Fig. 3).

El Pinar (MIS 5-4) is of interest because it is the only dated open-air site in the stratigraphic context from the Valencian region. There are some dating problems due, in large part, to the precise location of the dated samples (Casabó and Rovira 1992). In spite of this, it is relevant due to the existence of what these authors called a 'structure'. Faunal remains have not been preserved, and the lithic assemblage $(n=625)$ seems to include both Middle and Upper Palaeolithic materials. The reduction sequences are not precisely defined, and only the retouched artefacts (mainly side-scrapers [64\%] and denticulates [17\%]), together with some Levallois flakes and a few small Levallois cores, have been highlighted. From the spatial point of view, a concentration of flint pebbles together with other rocks was documented, forming an oval structure of about 3.6 by $2.3 \mathrm{~m}$ in its maximum dimensions. Its location, $10 \mathrm{~cm}$ higher than the rest of the level, contradicts the notion that this accumulation was formed by the old torrent. No complementary structure was observed, although some charcoal and thermally altered artefacts were present; these were interpreted as an anthropogenic accumulation with the intention of forming a thick gravel floor that would isolate humans from the humid clay soil. The spatial distribution of the tools showed an important concentration in one sector of the structure and near its edges, in contrast to some areas that were very rich in flint but without knapped artefacts. Casabó and Rovira (1992) interpreted this assemblage as a workshop.

In Cova Negra, Level III (MIS 5) is the unit studied in more detail from the excavations carried out in the west sector (Levels II to V). This level has a low number of lithic remains $(n=35)$ and combustion structures $(n=3)$ that are characterised by being simple, flat, lenticular in section and, in some cases, associated with cobbles (Soler 2003). The excavated area is $12 \mathrm{~m}^{2}$. A low density of lithic scatter with a dimension of about $10 \mathrm{~m}$ in its major axis, associated with various combustion areas and bone remains, was identified. The morphology was more or less elliptical and limited at one end by a large block of about two meters in length (Villaverde et al. 2009). The block, which determines the only living space, and the proximity of the cave wall led to the repeated occupation of this space, characterised by a low density of lithic and bone remains and alternating occupations of carnivores and Neanderthals, as indicated by the study of the marks preserved on the bone surfaces (Martínez Valle 1996, 2009). In this sense, the data suggest behavioural patterns conditioned by the physical nature of the different places and the sedimentary processes of each specific level. Numerous aspects, such as the presence of various species of bats with death ages that indicate hibernation periods and breeding colonies, as well 


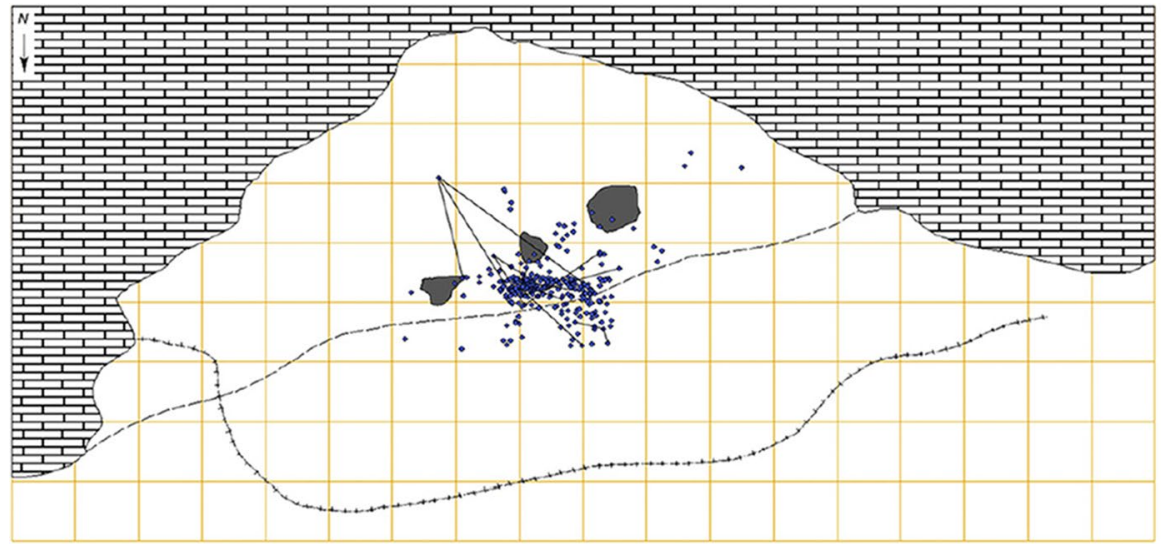

Pastor IVb

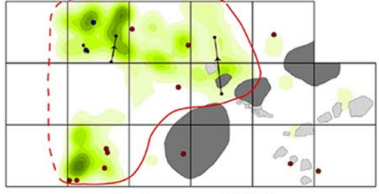

Bolomor IV-2

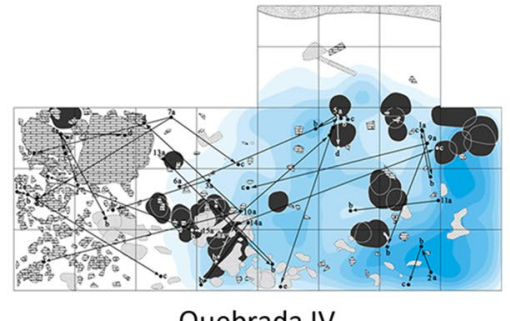

Quebrada IV

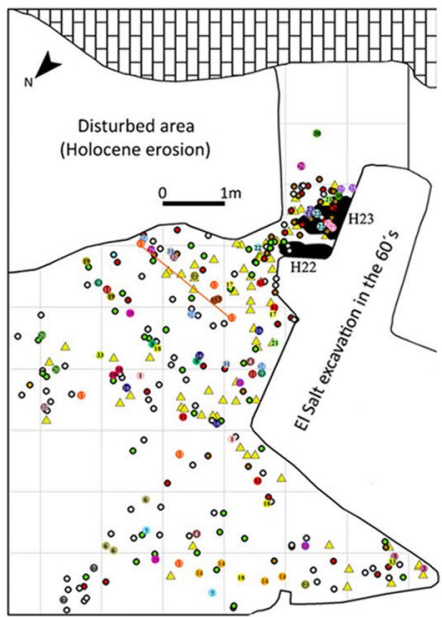

Salt X (3.2)

Fig. 3 Pastor IVb, Bolomor IV-2, Quebrada IV and Salt X (Unit 3.2) surfaces at the same scale. This image also provides a sense of the general site structure, including the refitting connections (from Sañudo and Fernández Peris 2007; Eixea et al. 2011; Machado et al. 2013, 2017)

as the marks and remains of various carnivores, indicate long periods during which the cave was not occupied by humans. The rest of the levels, for example Level XII from the south sector (MIS 6), present similar characteristics to those mentioned above, even though changes in the lithic densities (14 pieces $/ \mathrm{m}^{3}$ in Level II, 5.7 in Level IV, 18 in Level V and 16.7 in Level XII) and in the number of square meters excavated (from $12 \mathrm{~m}^{2}$ in Levels II-VI to c. $2 \mathrm{~m}^{2}$ in Level XII) are evident (Villaverde et al. 2009).

In Quebrada, the contrast between Levels IV (MIS 5-3) and VIII (MIS 5) affects practically all lithic features and, to a lesser extent, also the faunal record. These differences can be related not only to the rhythms and character of the 
occupations but also to other circumstances that are probably better explained by deep differences in the territorial occupation system and the functionality of the settlements (Eixea et al. 2011; Villaverde et al. 2017). Thus, it seems reasonable to think that the spatial occupation pattern was changing throughout site formation. While at Level IV the data suggest short and repetitive occupations focused on the hunting and processing of animal carcasses, Level VIII presents more sporadic visits with similar objectives but carried out by smaller groups. The following data point to this conclusion:

1. the density of remains (3156 lithic remains $/ \mathrm{m}^{3}$ in Level IV against 23.9 in VIII-1, 41.6 in VIII-2 and 37.4 in VIII-3);

2. the frequency of thermal damage in the lithic and bone material, because the degree of alteration is not only determined by occupation intensity but also by the degree of overlapping of the different occupations. The quantitative differences are again especially marked in the bone remains. While $60 \%$ of bone remains in Level IV display thermal alterations, this figure barely reaches $6 \%$ in the three sub-units of Level VIII. The number of combustion structures also highlights these differences. In the $30 \mathrm{~m}^{2}$ excavated surface, 29 hearths were identified in Level IV, nine in sub-levels VIII-1 and VIII-2, and none in VIII-3. A greater similarity between these values would be expected if the cause of their decrease were exclusively of a sedimentary order and related to the overlapping of the hearths and waste of previous occupation events. This suggests that the intensity or duration of occupations and their functionality may be the reasons for these differences;

3. the characteristics of the lithic industry and the fauna, since far from being two levels of similar items that differ only in the frequencies of their materials, Levels IV and VIII present significant differences in reduction methods (30\% of discoid knapping in Level IV and $>45 \%$ in Level VIII; $>30 \%$ of Levallois knapping in Level IV and $<20 \%$ in Level VIII); the raw materials used (70\% of flint and $20 \%$ of limestone and quartzite at Level IV against $>90 \%$ of flint throughout Level VIII); the rate of transformation of the flaking products by retouching (30\% for IV and $50 \%$ for VIII); and the integrity of the reduction sequences (more complete in IV, more fragmented in VIII). The same differences are observed in the relative importance of the main herbivores transported to the site (Caprinae are dominant in Level IV, Equidae are dominant in Level VIII) (Sanchis et al. 2013; Villaverde et al. 2017).

Unit X of Salt (MIS 3) is $35 \mathrm{~cm}$ thick and an area of $36 \mathrm{~m}^{2}$ was excavated yielding around three thousand lithic artefacts and more than six and a half thousand bone elements. The spatial organisation is typical of multifunctional areas, not only in terms of components (food preparation, consumption and production and maintenance of tools) but particularly in relation to the concentric pattern that shows the dispersion of remains around hearths (Marrero et al. 2011). The accumulation pattern in the surroundings of the hearth-related assemblages shows great complexity, because they are integrated by the association of different 
archeo-sedimentary facies (ASFs) containing an important concentration of hearths $(n=46)$. For example, in the case of ASF 4 and ASF 5 a sequence of up to eight combustion structures has been described, the stratigraphic relations of which indicate the superposition of different occupational events, showing the palimpsest character of the accumulations. In AFA 5, a bifocal organisation was also recognised, based on the articulating role played by two groups of hearths, with significant differences between them (Marrero et al. 2011; Machado et al. 2011). This pattern is a consequence of a behaviour that diffuses the different occupational events. In fact, it is not easy to specify the degree of relation and diachrony between the different accumulations. The identification of the occupational discontinuity suggests that there are at least two occupations in this space; nevertheless, we cannot be sure that they are the only ones. Not surprisingly, the intra-stratification of archeo-sedimentary facies and the existence of different thermal events have made it possible to propose a minimum of two occupations for AFA 4 and three for AFA 5. This unit is therefore characterised by the overlapping of different occupational events, not very far apart in time, so that possible short time gaps appear blurred, to the point of not being recognisable in the vertical distribution of the remains. When human occupations are successive and repeated in the same space, over short time scales, sterile sedimentary units are difficult to define (Machado and Pérez 2016; Leierer et al. 2019; Mallol et al. 2019; Mayor et al. 2020).

Finally, in Cova Beneito, the spatial data for Levels X (D1 and D2), XI (D3) and XII (D4) are scarce due to the smallness of the excavated area: $6 \mathrm{~m}^{2}$ in D1 and $3 \mathrm{~m}^{2}$ in the rest of the levels. In spite of this, the densities of the lithic material are high, especially in units D1 and D2 (more than 400 pieces $/ \mathrm{m}^{3}$ in D1, 692.4 in D2) but also, although to a lesser extent, in basal Levels D3 (446.7 pieces/ $\mathrm{m}^{3}$ ) and D4 $\left(277.5\right.$ pieces $\left./ \mathrm{m}^{3}\right)$. Two combustion structures have been found in these levels. In D1, a simple hearth of lenticular morphology, $0.8 \mathrm{~m}$ in diameter and made on a large limestone block, constitutes the main focus around which the vestiges are distributed. The second hearth, in unit D4, is characterised by an oval morphology and low thickness, is $0.5 \mathrm{~m}$ in diameter, and is delimited by 11 limestone blocks of between 4 and $15 \mathrm{~cm}$ in diameter (Iturbe et al. 1993). The Beneito cave dominates a wide ecosystem between the valley and mid-mountain areas and is well oriented, with water, raw materials and hunting available in the immediate environment. Some bones with carnivore marks indicate periods in which the cave was not inhabited by humans within a context of sporadic and short occupations (Iturbe 1991; Iturbe et al. 1993).

\section{Discussion}

\section{The Sites and Their Territory: Natural Corridors and Pathways}

In the central region of the Mediterranean Iberian Peninsula Neanderthals exploited different and interconnected physical territories, including coastal plains and the rear area of high ground and mountainous ranges up to $700 \mathrm{~m}$, such as at the Quebrada and Pastor sites. Usually humans occupied caves and rock shelters in not very 
elevated locations and selected places easily accessible from a nearby flat area. The relative altitude was usually below $50 \mathrm{~m}$ compared to the local watercourses, for three main economic reasons: (1) flat or gently sloping areas allow easier and faster relocation; (2) water is available and usually abundant; and (3) these territories are generally quite rich biotopes. However, sites in high and inaccessible locations have also been identified, most probably in relation to diversified economic needs and activities. The cave entrances and the position of the rock shelters showed a preference for sunny locations, with a prevalence of sites oriented to the east (Cova Negra and El Salt) and northeast (Quebrada and Bolomor), and, to a lesser extent, the southeast (Pastor) and southwest (Beneito). However, according to Aura et al. (1993) the issue of site orientation in the Valencian region is confused by the natural orientation of the local mountainous geography. Furthermore, comparative studies of sites with archaeological deposits and sterile cavities are lacking, and we suggest that this aspect must also be considered. The inclination to inhabit sunny places has also been clearly shown also in other regions of the Iberian Peninsula, where northoriented sites are usually underrepresented (Cortés 2007; Zilhão and Villaverde 2008; Arrizabalaga and Rios 2012; de la Torre et al. 2013; Álvarez 2014; Rios and García 2015; Rios 2017).

Given the complex orography of the Iberian and Bética ranges, it is difficult to deduce a general pattern of the distribution of Middle Palaeolithic sites in the central Iberian Mediterranean region from a macrospatial point of view. As Aura et al. (1993) pointed out, in a large number of cases the relationship of human occupation with a river course seems clear. This is the case in the north, with Tossal de la Font, Forcall Rambla Millars, Terrasa Pont Nou, Terrasa Pont Vell and El Pinar all strictly connected to the Millars river corridor, which joins the Teruel area close to the site of Eudoviges (Barandiarán 1975). Hoya Albaida-Titonares and Árguinas-Majadal, further inland, are linked to the Palancia river corridor located less than $5 \mathrm{~km}$ to the south (Table 5). In the central part, Abrigo de la Quebrada seems to be linked to the corridor of the Turia River, although it is located $5-15 \mathrm{~km}$ from the site. San Luis and Carcalín sites are located less than $5 \mathrm{~km}$ from the Magro river, a course that joins the interior plateau with the Valencian coastal areas, while the Rambla de los Morenos, at a slightly greater distance of 5-15 km, and Las Fuentes, at $<5 \mathrm{~km}$, would be related to the Júcar course. Regarding the southern zone, it is more difficult to establish the link with these pass areas. While Cova Negra and Cova de la Petxina are located a few metres from the course of the Albaida River, which facilitates passage (via the Serpis corridor) to the Vinalopó river valley, where the Cueva del Cochino and La Coca are located ( $<5 \mathrm{~km}$ from the river in both cases), the rest of the sites of this nucleus are confined to the coastal plain, as is the case with Cova del Bolomor, Cova del Gat, Cova Foradà, Cova dels Corbs and Calaveres. Finally, along the Serpis river course we find the sites of Bancals de Pere Jordi, Penya Roja, Beneito, Ermita de Santa Bárbara, Pastor, El Salt, L’Alt de la Capella, Aigueta Amarga, l'Alquerieta and La Solana. This fluvial course is where most of the flint for use in tool production in the above-mentioned sites is obtained (Molina 2016).

Neanderthal sites show a clear, strong relationship with natural corridors. This strategic settlement pattern reflects the high degree of adaptation to the environment of these populations and their capacity to maximize the exploitation of the territory 
Table 5 Sites, related fluvial course and distance between them (in $\mathrm{km}$ )

\begin{tabular}{|c|c|c|}
\hline Site & Fluvial course & Distance (in km) \\
\hline Tossal de la Font & Millars & $5-15$ \\
\hline Forcall Rambla Millars & Millars & $<5$ \\
\hline Terrasa Pont Nou & Millars & $<5$ \\
\hline Terrasa Pont Vell & Millars & $<5$ \\
\hline El Pinar & Millars & $5-15$ \\
\hline Hoya Albaida-Titonares & Palancia & $<5$ \\
\hline Árguinas-Majadal & Palancia & $<5$ \\
\hline Abrigo de la Quebrada & Turia & $5-15$ \\
\hline Barranc Carcalín & Magro & $<5$ \\
\hline San Luís & Magro & $<5$ \\
\hline Rambla de los Morenos & Júcar & $5-15$ \\
\hline Las Fuentes & Júcar & $<5$ \\
\hline Bolomor & Coastal plain & $<5$ \\
\hline Cova del Gat & Coastal plain & $<5$ \\
\hline Petxina & Albaida & $<5$ \\
\hline Cova Negra & Albaida & $<5$ \\
\hline Cova Foradà & Coastal plain & $<5$ \\
\hline Bancals Pere Jordi & Serpis & $<5$ \\
\hline Penya Roja & Serpis & $<5$ \\
\hline Cova dels Corbs & Coastal plain & $<5$ \\
\hline Cova de les Calaveres & Coastal plain & $<5$ \\
\hline Cova Beneito & Serpis & $<5$ \\
\hline Ermita Santa Bárbara & Serpis & $<5$ \\
\hline Cova del Cochino & Vinalopó & $<5$ \\
\hline Pastor & Serpis & $<5$ \\
\hline El Salt & Serpis & $<5$ \\
\hline L'Alt de la Capella & Serpis & $<5$ \\
\hline Aigueta amarga/Alquerieta/Solana & Serpis & $<5$ \\
\hline La Coca & Vinalopó & $<5$ \\
\hline
\end{tabular}

through mobility, knowledge and flexibility (Aura et al. 1993; Fernández Peris 1994; Mochales 1997; Fernández Peris and Villaverde 2001). Some differences can be highlighted according to geographical characteristics, and it is possible to define four contexts. The first location is the foothills, which allow a view overlooking the open and wide valley where human groups could easily move. Archaeological sites located in this geographical context are Cova Foradà at the eastern limit of Serra de Mustalla, with the northern valley and the southern Pego marsh; Tossal de la Font, located over an extended plain surrounded by mountains; Cova del Corb, which from its location on the Serra de Segaría overlooks the coastal plain; and Cochino, which dominates a flat area in a natural corridor between the Meseta and the coast. The second location is the mountainous area close to the opening of the 
fluvial valley at its junction with the plain, as is the case with the neighbouring sites of San Luis and Carcalín, situated at the edge of the Sierra de la Cabrera between the massif and the valley floor. Similarly, Las Fuentes in the Canal de Navarrés, Bolomor on the foothills of Mondúber massif, and Cova de les Calaveres overlook extended plains adjoining steeper territories. The third geographical location is the enclosed area between high reliefs which may be mountains, as in the case of the El Pinar site, or abrupt cliffs, such as Abric del Pastor and Quebrada, and even almostenclosed areas over a plain close to the fluvial valley, such as El Salt. Finally, the fourth location is the relief over two connected plain areas: the sites of Cova Negra and Petxina are situated at the River Albaida pass, between the Xativa plains; and the Cova Beneito site is located at a considerable height over the Agres River in between the Alcoi valleys.

Except for those situated in enclosed areas, the Valencian sites were located close to transit corridors connecting the hills and the littoral area or the internal reliefs and the coast. According to several authors (Aura et al. 1993; Fernández Peris 1994; Fernández Peris and Villaverde 2001), the strong relationship between Lower and Middle Palaeolithic sites and the natural corridors was related to the interrelation between human groups and herds of migratory ungulates. In contrast, during the Upper Palaeolithic, areas of topography that were difficult to access were also inhabited.

During the Middle Palaeolithic there was a preference for sites at low altitude in relation to the local plain, characterized by control over a limited territory, usually with a quite distorted topography, with access to water and a sunny location. The exceptions are sites dominating an extended territory placed at the intersection between different biotopes, such as Cova Negra and Bolomor, and sites with difficult access, placed at points high enough to overlook transit pathways such as Quebrada, Pastor and El Salt. These exceptions imply a richer scenario. The evidence speaks against reconstructing any simple, monotonous Neanderthal spatial pattern, suggesting rather the intentional and planned selection of locations which had special relevance to an ability to adapt to a wide range of environments.

\section{Variability of Neanderthal Occupations in the Central Region of Mediterranean Iberia}

The diversification of technology in the studied region is evident and was not related to a specific settlement pattern. Most likely, the variability of technical strategies identified in the sites reflects different traditions rather than variations in settlement patterns (Eixea 2018). As noted in other regions (Bourguignon et al. 2006; Richter et al. 2007; Durand et al. 2009; Daujeard and Moncel 2010), an unresolved question is whether the technical and economic patterns identified in caves and rock shelters were also characteristic of open-air sites, which have rarely been identified. According to the currently available data from El Pinar (Castellón), La Coca (Alicante) and Els Bancals de Pere Jordi (Alicante), in the Valencian area the same variability in technical behaviour has been described for open-air sites and cavities and rock shelters (Casabó and Rovira 1992; Fernández Peris 1998; Eixea and Villaverde 2012). 
The reduced distance of the sites from raw material outcrops could explain the high rate of cores at El Pinar and La Coca, as well as the presence in situ of the first phases of the production sequences. In contrast, the Els Bancals de Pere Jordi site, which is located at a great distance from raw material sources, is characterized by the lowest rate of these technical categories.

The production of stone tools was one of the central activities in most of the sites. It is possible to identify a correlation between long-term occupations and the hunting of a main taxon with predominant Levallois (El Salt X) or discoid production (Beneito X) (Iturbe et al. 1993; Machado et al. 2017). By contrast, at Bolomor, Quebrada and Pastor the occupations were mostly short-term and associated with a great variability of technical behaviour, including Levallois, discoid, trifacial and Quina (Cuartero 2007; Galván et al. 2009; Machado et al. 2013; Eixea 2015). The distance to resources did not necessarily result in a fragmentation of production across the landscape: exogenous materials collected from up to a hundred kilometres away were in some cases knapped at distant sites (Eixea et al. 2011, 2014). The retouched toolkits usually lack diversity, with a generalised predominance of scrapers (Quebrada, Pastor, Salt, Cova Negra, Beneito and El Pinar) over denticulate tools (Bolomor, Beneito XI and XII). Not many Upper Palaeolithic stone tools have been documented; the lowest rate $(<5 \%)$ has been identified at Pastor IV in association with a very low-density human presence, while the highest was recognized at Quebrada VIII and Bolomor XII and XVII (40-50\%). In these archaeological levels all the various stages of the production sequences were attested, associated with shortterm, recurrent human occupations. At Quebrada IV and Bolomor IV the Upper Palaeolithic group constituted $20 \%$ of the recovered assemblage, and could be seen to be associated with short-term occupations that accommodated butchering activity. Another example of the variability of this technological group was Cova Negra III, where the presence of Upper Palaeolithic tools was associated with a high rate of fragmentation of productive sequences, suggesting a high temporal fragmentation and alternation between humans and carnivores at the site.

Concerning retouching, the index of reduction was usually low, and retouching removals were minimally invasive compared to the original morphology of the edge, except for the Quina and demi-Quina scrapers identified in the basal layers at Cova Negra and Bolomor (MIS 8-6), and for some resharpening and recycling activity identified in more recent chronology at Quebrada, Pastor and El Salt. Points and tools with convergent morphology seem not to have been related to one specific task. The characteristics of use traces and fractures suggest instead that these artefacts were used as a great variety of different tools, including drills, side-scrapers, end-scrapers and projectiles (Galván et al. 2007; Eixea et al. 2015). The variability of occupation strategies seems to have most likely been related to cultural traditions and was reflected in the technical behaviours.

Productive sequences were usually realized at the site, regardless of the site's function. Usually few elements were transported and introduced into the site, including flakes and cores, at the initial phase of exploitation, as has been documented at Cova Negra, Quebrada, Pastor and El Salt. However, in transit zones where sites were only occupied briefly, the production sequences were often fragmented in relation to the various raw materials, such as flint (Bolomor and Pastor), quartzite 
and limestone (Quebrada) (Fernández Peris 2007; Machado et al. 2013; Eixea et al. 2016). Neanderthals mainly exploited local flint resources in association with other secondary raw materials. The flint acquisition was mainly focused on Mesozoic and Neogene limestone deposits, which are available over an extended territory yet with variable quality and petrographic characteristics. Examples of 'typical' Neanderthal organisation are Bolomor IV, EL Salt X and Beneito XI and XII. At these locations flint resources are collected within a radius of $20 \mathrm{~km}$ from each site and were transported to the site as nodular blocks and as flakes. The same strategies were applied for local limestones and quartz, suggesting a recurrent planning at the base of techno-economic strategies. However, the predominant use of limestone and quartzite at Quebrada for Levallois production in a geological landscape where flint was abundant and easily available less than ten kilometres from the site suggests that Neanderthals' technical behaviour was highly versatile and not determined by environmental context. Most likely the exploitation of resources other than flint for Levallois production at this site was related to mobility and settlement patterns in the territory, as well as the duration of occupation at the site and the tasks conducted there. At the sites inhabited during short-term occupations and for specific activities such as butchery, the raw material catchment was usually expedient and focused on the immediately available resources and independently on the knapping methods applied and the petrographic characteristics of the raw material. This behaviour had consequences with respect to the degree of retouching and resharpening of tools. At Quebrada, for example, the raw material diversification associated with Levallois production was related to a reduced technical investment in retouching, suggesting a brief use of tools mainly for butchery and consumption (Plisson 1985, 1986; Geneste and Plisson 1996; González-Urquijo and Ibáñez 1994; Eixea et al. 2016). With short-term occupation and brief use of tools, a distantly-located raw material catchment was not worth the time invested. In contrast, the search for homogeneous, high quality raw materials, independent of their distances from the site, was worthwhile in the case of long occupations characterized by long, in situ productive sequences and the long-term use of tools. Furthermore, raw material quality must be taken into account when analysing techno-economic behaviour. In the case of Quebrada, for example, the local quartzite was characterized by high homogeneity and a fine grain, unlike the local flint. These data reinforce the hypothesis that raw material did not a priori determine the knapping method, and that resource selection was based on several additional factors.

Traditionally, the high quality of flint has been considered the main cause of the predominant use of this resource during the Middle Palaeolithic. This idea has most probably been biased by the petrographic and qualitative characteristics of flint outcrops in specific European regions where techno-economic studies were first developed. Data from Valencian sites, as well as from other sites in France, Italy, and the rest of the Iberian Peninsula, suggest a much richer and more complex scenario (Marks et al. 2001; Mussi 2002; Cauche 2002, 2007; Baena et al. 2005; Mourre and Thiébaut 2008; Mora et al. 2008; Rios 2010; Santamaría 2012; Álvarez and Arrizabalaga 2012; Romagnoli et al. 2016a, b; Eixea 2018). Neanderthal behaviour in relation to raw material could have been affected not only by technical traditions but also by specific, practical needs. Furthermore, the visibility and accessibility of 
raw material could have been much more significant than quality, and could have in some ways affected the frequent use of 'alternative' raw materials for Levallois production, as well as the predominance of discoid knapping in some regions. The difficulty of procuring raw materials with specific qualities has also been proposed in relation to the long-term use of Quina tools (thanks to the intense resharpening allowed by the thickness of the blanks) in southwest France during the Middle Palaeolithic (Turq 1992).

Due to the difficulty of interpreting technological variability with raw material quality, it is necessary to consider other factors, such as climatic constraints, site function, the duration of occupation and the availability and abundance of resources in the foraging area. The knapping system is related not only to the tasks realized at the site but also to the availability of raw material nearby and the potential for resharpening of the flakes. Expedient technologies represent a particular technoadaptive choice in an environment, which could also be adapted to with an entailed and enchained technology (Meignen 1988; Jaubert and Farizy 1995; Mourre 2003; Slimak 2003; Mora et al. 2004; Vaquero 2011; Rios et al. 2011; Baena et al. 2017), and the study of different degrees of technical investment is highly important to an understanding of the archaeological assemblages (Vaquero and Romagnoli 2018). At Quebrada sedimentary and anthracological data suggested that the three studied layers, corresponding to the upper part of the sequence, were deposited during cold climatic conditions and with a vegetation dominated by Pinus nigra (Badal et al. 2012). The layers are palimpsest, and the low temporal resolution prevents the detection of possible links between the technological behaviour, the use of the space, and the hunting strategies. However, in Layer IV the presence of discoidal cores at the base of the layer, some differences in the areas where red deer carcasses were processed compared to the areas with remains of horses and Iberian wild goat, and the presence of turtle remains in the central part of the excavated area suggested a possible diversified use of the space (Eixea et al. 2011). The site elevation at 790 masl, and the present climatic conditions suggest that during some period of occupation at the site the area was covered with snow. Between Layers III and IV no significant climatic or environmental changes have been identified, and the site seems to have been used for similar economic and occupational behaviours, as suggested by similar taxa and fragmentation rate of faunal remains, density of remains and number and spatial distribution of hearths. However, some differences in percentage between Levallois and discoid productions, and in the presence of Levallois productive sequences made of quartzite and limestone, have been highlighted (Eixea 2012; Villaverde et al. 2012; Eixea et al. 2016). These data suggest that local raw material availability had a secondary importance. The difficulty is directly linked with raw material characteristics and technological organization looking at the relation between mobility patterns and expedient technologies (Parry and Kelly 1987; Andrefsky 1994; Wallace and Shea 2006; Vaquero and Romagnoli 2018).

The comparative study of faunal assemblages at a regional scale of analysis does not allow us to identify taphonomic and zooarchaeological processes in relation to occupational patterns. The available data in the studied area suggested the exploitation of different ungulates in the majority of the sites. At Quebrada IV, Cova Negra II and III and Beneito XI and XII, the high occurrence of goats 
(caprinae) probably relates more to their high availability in the landscape than to any specialised and selective hunting strategy. Similar conclusions have been proposed for horse at Quebrada VIII, Pastor IV, Cova Negra IV and V and Bolomor XII, and for deer at El Salt X and Bolomor IV and XVII (Martínez Valle 2009; Morales and Sanchis 2009; Blasco 2011; Salazar-García et al. 2013; Sanchis et al. 2013; Machado and Pérez 2016). Furthermore, transport strategies were related to the landscape topography and ease of access to the site. At Quebrada or Pastor, for example, which are difficult to access, the faunal remains accumulated by humans are represented by the cranial and appendicular portions of the skeletons, and the small size Bovidae are usually complete and were introduced by carnivores.

In conclusion, during the long chronological span of the Middle Palaeolithic, the documented deposits do not present a clear association between the different technical and typological traditions, the type of economic activity and the duration of the occupations. Sometimes the degree of resolution of the levels studied, given the date of excavation, does not facilitate this type of assessment. These circumstances differ from those apparent in the sites of southwestern France, where the different technical traditions of the prehistoric groups are interpreted as a result of mobility and settlement pattern strategies (Delagnes and Meignen 2006; Bourguignon et al. 2006; Delagnes and Rendu 2011). It is reasonable to assume that physical topographic characteristics, such as altitude, geographic location, accessibility and visibility, were relevant for humans, and it is likely these conditions affected the duration and intensity of human occupations. Furthermore, in the studied region the variability in the use of locations by Neanderthals was probably also affected by paleoenvironmental conditions, and by variations in the rhythms of human or carnivore presence-for example, the suitability of caves or shelters for use as dens, in terms of protection and accessibility.

The available data allow us to differentiate two types of deposits. The first type includes those with high indices of carnivore occupation and low densities of human remains, both in terms of faunal contributions to consumption and the processes of manufacturing and use of lithic instruments. Within this type it is possible to observe variations in the importance of remains contributed by carnivores, with deposits in which the density of anthropic remains is especially low, while the evidence of carnivore contributions is elevated. Cova Negra Level II is an example of this, with a low lithic density of 3.9, and a relatively high proportion of carnivore bone remains compared to that of herbivores (7.3\%), and a better documentation of carnivore as compared to anthropogenic marks. Other sites have more moderate rates of carnivore presence, even if the anthropic contributions are also low. This could be related to various scenarios:

a. sporadic occupations by humans alternating with sporadic occupations by carnivores. For example, Quebrada Level VIII, with few identified carnivore remains, some of anthropic origin and some produced by carnivores, and a moderately low density of lithic remains (with indices between 23.9 and 41.6); 
b. temporary occupation by carnivores scavenging remains left by humans. This is the case with Bolomor Level XII, with a low lithic residue density (49.7), even though the carnivore remains are low $(0.4 \%)$, as are their marks $(3 \%)$; and

c. human occupation associated with a confrontation with scavenging carnivorese.g. Beneito phase D3, with moderate lithic density and a low number of carnivore remains as compared to those of herbivores, but with very high percentages of their marks on skeletal remains (21.8). Regarding the different sub-levels of Pastor IV, with moderately low lithic densities, the absence of faunal data limits its characterisation.

The second type includes those in which remains of anthropogenic origin are elevated and the remains of carnivores proportionally very reduced. This is the case with Bolomor Level IV, with a very high index of lithic remains (1178 pieces $\left./ \mathrm{m}^{3}\right)$, and Quebrada Level

IV (3156). In the latter case, if the chips are omitted, this index remains at 390, compared to a value of 573 at Bolomor, following the same criteria. In both cases the anthropic marks exceed those of the carnivores, the percentage of carnivores with respect to herbivores is low and evidence of processing through hearths and of the processes of fracturing are high, with low percentages of identified bone remains. In the case of Quebrada, the fracturing and thermal alterations are consistent with the intense processing of food. Other sites that coincide with this model are El Salt Level X and Beneito D2 and D4, with low percentages of carnivore marks on skeletal remains, low proportions of carnivores and moderate proportions of lithic remains. As in the previous type, there are variations in the density of lithic remains, in the relative importance of hearths or in the proportion of carnivores, but in all cases anthropic contributions predominate over those of carnivores, which never reach high values.

It is noteworthy that some places may have variations in different aspects, such that these two types of settlements, or their variants, cannot be explained exclusively by topographic factors (accessibility, site position, water and animal ressources, among others). Nor is there a chronological gradient in the ordering of the two types of occupations described. Therefore, the variations must be motivated by changes in occupational pattern systems that could be related to paleoenvironmental variations or variations in demographic densities of human groups associated with the corresponding adjustments or changes in the territorial pattern systems, in the use of the space of settlements and in the acquisition and management of alimentary resources.

Furthermore, Neanderthals managed the territory where they lived in similar ways irrespective of latitude. This means that these populations were highly adaptable to variations in resource availability, and that they organised seasonal displacements and economic strategies according to their knowledge of the territory and planning capacity. A similar situation obtains with the utilisation of lithic raw materials. The lack of clear differences in settlement patterns in the studied area also suggests that the rules governing Neanderthals' technological and socio-economic organisation were, everywhere, similar except for strictly local characteristics related to micro-topographic territory and possible functional factors. Knowhow and 
experience seem to be more important than technological traditions when settlement pattern is considered.

\section{Variability of Neanderthal Occupations in the Context of Southwestern Europe}

To broaden the approach to the variability of occupation dynamics we must take into account the data from southwestern Europe. This region includes the northeastern area of the Iberian Peninsula, the southeast of France and Italian Liguria. In relation to the northeastern area of the Iberian Peninsula, the variability of Neanderthal occupations can be synthesised by distinguishing two types of archaeological contexts. First, there are assemblages that are clearly related to human activity and that can be characterised as residential complexes. This is the case with sites such as Abric Romaní, Roca dels Bous, Cova Gran, Cova del Estret de Tragó and Fuentes de San Cristóbal (Casanova et al. 2009; Marín et al. 2019; Martínez-Moreno et al. 2010; Mora et al. 2004; Rosell et al. 2000; Vaquero et al. 2001; Vallverdú et al. 2010). These assemblages present a higher number of archaeological remains-evidence of the realisation of knapping activities at the site and faunal assemblages produced essentially by humans that show a lower impact of carnivore activities. In some cases (e.g. Abric Romaní, Roca dels Bous, Fuentes de San Cristóbal, Cova Gran), the presence of fires around which many of the activities took place confirms the residential component. These sites are rock shelters located along natural pathways that link different geographical units. This is the case with Abric Romaní, located at the Strait of Capellades, which connects the Ebro Depression with the coastal and pre-coastal regions. Also, several deposits (Cova Gran, Roca dels Bous, Estret de Tragó, Fuentes de San Cristóbal) are located in valleys with a N-S orientation that link the Ebro Depression with the Pyrenees and the Pre-Pyrenees. These data suggest that mobility and the access to paths of natural communication played an important role in the localisation of these residential contexts. Second, there are numerous sites characterised by a low incidence of human activity in the NE Iberian Peninsula. These contexts are composed of small lithic assemblages associated with faunal assemblages formed mainly by natural processes (animals falling into natural traps, carnivorous activity). These are generally cave sites located in the steep landscapes of the Coastal or Pre-coastal Cordillera (Cova del Rinoceront, Cova dels Ermitons, Cova 120, Cova de Coll Verdaguer, Cova del Gegant, Cueva de Mollet) (Daura et al. 2010, 2015; Maroto et al. 1996, 2012; Sanz et al. 2016; Terradas and Rueda 1998). The human activity would be related with short visits to exploit naturally-occurring resources, or for occasional use of the sites for shelter. Knapping activities were rare or non-existent, and the lithic assemblages are mainly composed of transported tools (toolkits formed by big flakes, retouched artefacts and cores). We cannot rule out the introduction of lithic remains by natural processes and their accidental association with the faunal remains. One of these two types of formation contexts is predominant at the sites previously cited. Nevertheless, in some sites these contexts are successive over time as a result of the use of the caves in alternation by humans and carnivores. These archaeological assemblages sometimes show a predominant activity of carnivores at the same time as residential occupation dynamics. The Teixoneres Cave and the Cueva de los Moros de Gabasa belong to this group of sites. In both cases, this 
alternation between humans and carnivores is associated with a differential spatial patterning of the remains produced by each of these agents. At Level III of Teixoneres, the hearths and the other remains from anthropic activities are concentrated in the outer part of the cave near the entrance, whereas the carnivores appear to have preferred the inner part of the cave (Rosell et al. 2017). The same pattern is observed at Level G of Gabasa (Blasco et al. 1996) and at Level I of the Cova de l'Arbreda (Maroto et al. 1996). In the latter, the large number of lithics knapped at the site suggests significant human activity, but at the same time, the abundance of bear remains indicates that these animals used the cave as a lair.

A large number of sites belonging to this period have been identified in southeastern France. We have focused on areas where the sites have been studied from an interdisciplinary viewpoint. The chronological range is from MIS 8-3. The first is the Middle Rhône Valley, especially the right bank, which has yielded more than ten Middle Palaeolithic sites (Moncel 2003; Daujeard and Moncel 2010; Daujeard et al. 2012; 2019; Raynal et al. 2013; Hardy et al. 2013; Moncel 2008, 2014, 2015; Richard et al. 2015; Baena et al. 2017, among others). The sites are located on low plateaux and along rivers between the Massif Central and the Rhône corridor. The majority of the sites are rock shelters or cave entrances with vast, easily accessible porches (e.g. Abri du Maras, Saint-Marcel, Le Figuier), but there are also narrow chambers opening out on to steep cliffs (e.g. Abri des Pêcheurs) or on a promontory facing different valleys (e.g. Payre) (Moncel 2008, Moncel et al. 2015). The sites' openings are south-facing with easy access to the rivers and to diverse environmental resources, especially stone raw materials and animals. The Abri du Maras site was occupied for short-term episodes of reindeer hunting in Level 4.1 (MIS 3) and as a residential campsite for long-term occupation events in Level 5 (MIS 5) (Marín et al. 2020). On the one hand, in Level 4.1, the lithic assemblage shows a predominant Levallois core technology, with some complete and some partial operative sequences (cores on imported flakes). The points, some flakes and the largest blades were introduced to the site already knapped. The raw materials used come from less than twenty kilometres to the north and south of the site, on the right bank of the Rhône (Moncel et al. 2014, 2015). The large fauna points to a cold and dry environment and an open steppe landscape favourable to large gregarious ungulates, with specialised autumnal short-term hunting episodes of reindeer herds (Daujeard and Moncel 2010; Daujeard et al. 2019). The 13 lenses of ashes and the use-wear data show a wide variety of on-site domestic activities (Hardy et al. 2013). And, on the other hand, in Level 5, the lithic assemblage shows a higher ratio of flake tools, including some large scrapers, possibly a limited introduction of already worked products and a higher quantity of whole pebbles in diverse stones collected along the Ardèche River. Mortality profiles indicate preferential selection of prime-dominated reindeer, red deer and horse, mainly killed during the summer. However, horses were also killed during the autumn, which could indicate different seasonal events. After capture, the transport of animal carcasses optimizes the food values of the transported elements, which is a typical pattern for sites used as residential camps (Marín et al. 2020). The site of Payre was first a cave and then a shelter before the collapse of the limestone ceiling. The lithic and faunal assemblages point to long- (Levels D and G) and shortterm (Level F) seasonal occupations and the exploitation of the surrounding resources (Moncel 2008; Chacón 2009; Rivals et al. 2009; Daujeard and Moncel 2010). The ash 
lens and the burnt flint and bones indicate the use of fire at the site. The lithic raw materials were collected in nearby rivers in a local and semi-local perimeter, and some flint flakes come from distances of 20-60 km (Fernandes et al. 2008). The lithic assemblage varies by level but is composed of small and some large flake tools and of pebble tools. The retouched tools on small flakes are composed of only side-scrapers and points. The debitage and shaping are similar in the three levels (D, Fa and $\mathrm{Ga}$ ), and the debitage is mainly of the discoid type, but other knapping methods have also been identified (Moncel 2008; Baena et al. 2017, among others). The Saint-Marcel site shows a succession of long-term residential camps from the faunal and lithic remains. The faunal accumulation is due to hominid activities. The predominant species is red deer, which was selectively hunted. Lithic analyses indicate a consistent technical behaviour over time, based on a discoid core technology on flint that was gathered on northern and southern plateaux and along the Rhône. Tools are rare and made up of side-scrapers and points (Moncel 1998, 2003; Moncel et al. 2004).

In the left bank of the Middle Rhône Valley, at the Massif central, the sites are also important (Fernandes et al. 2008; Daujeard et al. 2012; Santagata 2012; Raynal et al. 2013); among them the Sainte-Anne I cave and the Baume-Vallée rock shelter have several archaeostratigraphic deposits. The Sainte-Anne I cave is a small, south-facing cavity. Its lithic assemblage shows an adaptation to the available lithic resources as well as their volumes and mechanical limitations. They produce complete reduction sequences in quartz, volcanic rocks and local flint, the local resources. The sequences come from exogenous and semi-local rocks, which are fragmented and incomplete reduction sequences, and the products were transported to the site already knapped. Levallois and discoidal methods were used for the volcanic rocks, but orthogonal or some other unipolar flaking methods are also identified. Because of the nature and density of some of the raw material, bipolar anvil percussion is also used. The faunal assemblage is dominated by reindeer, horse and ibex together with woolly rhinoceros, bovines and other cervids. These species suggest severe climatic conditions like those that dominated during MIS 6. Carnivore remains are rare (Raynal et al. 2008, 2013). Baume-Vallée is a southeast-facing rock shelter located at the foot of a cliff. The lower part of the stratigraphic sequence has several archaeostratigraphic units belonging to the Ferrassie type of Charentian Mousterian. The main lithic raw material used is flint (90-73\%), and the predominant knapping methods are Quina and Levallois. Horse is the predominant species, followed by the cervids, ibex and bovines. Carnivore activity on bones is very rare and the majority of fresh bone fractures can be related to human activity (Daujeard et al. 2012). The site has been interpreted as a seasonal hunting camp (Fiore et al. 2005).

A number of important Middle Palaeolithic sites dated to MIS 5-3 are found in the Occitan region (the oldest of the Languedoc-Rousillon/Midi-Pyrénées regions) (Lumley 1971). This area began to be studied in the 1960s, but there has not been much synthesising work on the Middle Palaeolithic sites (including the Crouzade, Tournal and Ramandils caves). The new Programme Collectif de Recherches (Saos 2017) has attempted since 2014 to revise and update the stratigraphic sequences of these sites from an interdisciplinary point of view. The cave of Ramandils (MIS $5-4)$ is one of the richest sites in the region. It is located near the littoral, an area with a great number of local flint outcrops. The lithic assemblage is characterised by the predominance of Levallois knapping methods with a high proportion of 
scrapers (typical Mousterian; Moles 2008; Moles and Boutié 2009), and with a significant tendency to produce microliths. The very rich fauna, is dominated by species belonging to forest (Cervus elaphus, Dama dama and Sus scrofa), steppe tree-filled (Bos primigenius), and open environments (Equus caballus, Equus hydruntinus and Palaeoloxodon antiquus), and carnivores. In addition, we should note that the inhabitants exploited the coastal environment, as demonstrated by the remains of a considerable number of marine shells from consumption (among others, Mytilus sp., Cardium edule and Pecten jacobeus). The Crouzade is a west-facing cavity situated near the littoral. The lithic raw materials come from a radius of $20 \mathrm{~km}$, and the most used are flint, quartz and quartzite. The technological behaviours show a duality between the use of Levallois and discoidal knapping methods in all the levels. Quina and laminar debitage have also been identified (Lumley 1971; Lebègue 2012). The faunal assemblage is mainly composed of Equids (Equus caballus and Equus hydruntinus), reindeer, bos and bison. Carnivores are numerous (Ursus spelaeus, Panthera leo spelea or Vulpes vulpes) (Testu 2006; Boulbes and Moigne in Saos 2017). The site has been interpreted as a specialised site of seasonal occupation (in alternation with carnivores), dependent on a main base camp, which could be located in the Rhône coastal plain (Lebègue 2012; Saos 2017).

Finally, the Cave of Tournal is a west-facing cavity located at the foot of a $30 \mathrm{~m}$ high cliff. The lithic assemblages show a predominance of Levallois (centripetal recurrent) and discoidal debitage, with a high number of denticulates and notches. The goal of the reduction sequences is the acquisition of large-format pieces (normally without retouch). These knapping methods are the same in all the stratigraphic sequences, as is the raw material used (flint, quartzite and quartz, local and semi-local) (Tavoso 1987; Chacón 2009; Lebègue 2012; Grégoire in Saos 2017). The faunal assemblage shows that reindeer and horse were the primary prey taxa. Traces of carnivore action are common, suggesting destruction and secondary access to carcasses after the hominids abandoned the site (Magniez 2010). As for the Crouzade cave, Tournal has been interpreted as a site of seasonal occupation in alternation with carnivores (especially hyenas and bears) (Patou-Mathis 1992; Magniez 2010; Saos 2017).

In Liguria, Italy, several sites have been identified preserving Middle Palaeolithic deposits. The sites are located close to the present sea shore, usually at a very low altitude on the limestone littoral cliff (such as the rich complex of the Grimaldi sites in the Balzi Rossi and Grotta di Madonna dell'Arma) or four to five kilometres inland (Arma delle Manie, Grotta delle Fate and Grotta di Santa Lucia Superiore). Usually the openings of the caves and the walls of the rock shelters face southward, toward the sea. The faunal assemblages reflect a variety of biotopes exploited by Neanderthals, including humid, marshy, coastal areas with no hunting specialisation and climatic fluctuations during the Late Pleistocene. As in other European areas, the occupational patterns included different types of sites according to the duration of human frequentation and human/carnivore competition (Valensi and Psathi 2004). Grotta delle Fate and Santa Lucia Superiore were mostly used by denning carnivores. In these sites alternations of human and bear frequentations are suggested by the high percentage of carnivore tooth marks on macromammal bones. Unfortunately, the limited excavation volumes and the consequent paucity of any broader spatial observations mean that we cannot draw 
inferences about possible differences in intra-site spatial patterns between humans and carnivores (Tozzi 1963; Echassoux et al. 1989). Madonna dell'Arma was also probably repeatedly occupied by carnivores. However, the presence of hearths, also in the external rock shelter, and Layer I on the top of the sequence, dated at MIS5a-4 and with abundant lithic remains, suggested that this site could also have been used as a residential campsite (Isetti et al. 1962; Cauche 2007). Similar behaviour could be suggested at Grotta del Principe, where bear and hyena remains have been identified along the whole sequence (Palma di Cesnola 2001). Arma delle Manie is an example of a site with very low presence of carnivore and where humans were the main agent responsible for the formation of the faunal assemblage (Valensi and Psathi 2004). In every abovementioned site the occasional exploitation of carnivores for furs and meat has been identified (Valensi and Psathi 2004). The analysis of lithic production showed a generalised predominance of Levallois production, often aimed at obtaining elongated blade-like blanks (Tavoso 1988; Negrino and Tozzi 2008). However, it is possible to glimpse a patchy scenario with prevalent discoid and Levallois assemblages alternating in different caves (Cauche 2007) and along the stratigraphic sequence of several sites at the Balzi Rossi complex, where discoid production was frequently attested in the upper layers (Riparo Mochi; Kuhn and Stiner 1992; Barma Grande Layers 1-8; Ex-Casinó upper layer; Ex-Birreria B3, B4; Riparo Bombrini IV; Rossoni-Notter et al. 2017 and bibliography therein). The exploitation of core-on-flake was quite generalised during the Middle Palaeolithic (Cauche 2007; Rossoni-Notter et al. 2017) and was most probably a response to the mobility strategies and time constraints of local populations. The mobility of Neanderthals in Liguria during MIS 5-MIS 3 was characterised by a quite extended territory. Although local raw materials were usually the most exploited, sporadic exogenous resources have been continually identified at every site, and a high rate of fragmentation in productive sequences was often related to the distance of the outcrops, with raw materials collected far away and usually circulated in the form of finished tools (Cauche 2007; Grimaldi and Santaniello 2014; Rossoni-Notter et al. 2017). The region could be divided into three main 'economic districts' in relation to the location of flint, micro quartzite and jasper (Porraz and Negrino 2008; Tomasso et al. 2016). Flint outcrops were abundant in the western part of the region close to the French border, where lithic workshops have also been identified in the Eocene conglomerate of I Ciotti, which was the main exploited formation during the Palaeolithic in the Balzi Rossi complex (Del Lucchese et al. 2001). Several sites located in this district have shown the presence of flint and rhyolite from over fifty kilometres west in the French formations and sporadic jasper blanks related to outcrops located over a hundred kilometres east (Porraz and Negrino 2008). Furthermore, the main evidence for the Late Middle Palaeolithic of Liguria is concentrated in this district (Negrino and Riel-Salvatore 2018). Central-western Liguria was rich in micro quartzite and silicified limestone, and these resources were heavily exploited during the Middle Palaeolithic. In this area rich in caves with archaeological deposits, the archaeological assemblages often include an exogenous flint toolkit, attesting to the exploitation of eastern outcrops located at a maximum distance of approximately one hundred kilometres, and to both tools and cores made of jasper related 
to formation in the Apennines in eastern Liguria, Emilia Romagna and northern Tuscany (Porraz and Negrino 2008; Cauche 2012; Tomasso et al. 2016). Recently, the presence of possible sources of this raw material in the western part of the region has been proposed (Negrino et al. 2016).

With the data presented, what emerges from the different areas analysed is a similarity in the occupational and territorial patterns. In most parts of the sites, a high rate of lithic and bone remains is observed, frequently associated with typical palimpsest structures, in which recurrent brief, intense occupations take place over an indeterminate period of time. These are reflected in the record based on a structuring of the space around hearths, which are the central focus of activity, and the dispersion of archaeological remains in the surrounding area. The number of occupations that occurred in each event is difficult to identify, and we therefore cannot rely on any general interpretation of the sites as seasonal sites for hunting or butchering activities. In some cases between occupational episodes, and based on the site's own morphology (usually caves), there are alternations between humans and carnivores in the same space, which indicates considerable competition between them in the environment. While it is true that topographic factors influenced choice of habitation site (proximity to water resources, sources of raw material or areas of animal passage), the data suggests greater complexity, reflecting the adaptive capacity of these groups. Expedient versatility and ensuring access to the different territories were both factors defining the subsistence strategies. These strategies demonstrate considerable logistical complexity in the use of resources by these populations.

\section{Conclusions}

The multidisciplinary approach used here-focused on the different strategies for procurement and management of biotic and abiotic resources, as well as their reflection in the archaeological record-is an important aspect of the analysis of the use of territory and space by Neanderthal groups. Despite this, we must be cautious in interpreting the data, due to the fragmentation and partial nature of the information (lack of surveys in the territory, incomplete excavation data, scarcity of open-air site assemblages, lack of a good dating series, etc.). However, the results obtained from the combination of raw material procurement patterns, the management of tools, the access to and use of animal carcasses, and the possible functions of the sites constitute a first approximation in regard to the pattern of territorial organisation of these populations. The interpretations and conclusions that have been proposed must be verified and corroborated with new data from ongoing excavations and future work. In particular, we believe that the construction of a new dating series and an extension of detailed faunal analyses will allow a further refinement of our conclusions.

In spite of this, the model addresses the main questions we proposed in the introduction of the paper concerning the diversity of Neanderthal occupations, their different aspects and how they are reflected in the archaeological record. The image that emerges is of a complex panorama and a multitude of factors, some of which may have more importance than we can infer; there does not seem to be a single cultural, functional, temporal or environmental explanation. Wide variability in the observed 
technical behaviours is explained by reference to the needs of the populations in each specific region. As we have seen, an example of this is the predominance of a knapping system that exists at one level and that is associated with different types of settlement patterns and a different chronology. Similarly, the tools also do not seem to be linked to specific activities: side-scrapers dominate by a high percentage in most of the assemblages; those where they do not are dominated by denticulates; there is no economical or functional variation. As regards the fauna, no clear temporal differences are identified; it is more a question of topography, the variety of biotopes, the accessibility of resources and the location of places that exerted a greater influence on the types of activity carried out in the various sites. On the other hand, the mechanisms of procurement of raw materials follow a similar pattern throughout the territory. Procurement is mainly local, within a radius of around ten kilometres from the site. Normally, cobbles are introduced on unworked nodules, and they are exploited from the early stages at the site. In turn, a series of exogenous materials are sometimes identified, some located over a hundred kilometres from the original source. These items comprise a set of raw materials or transported pieces brought from previous settlements or procurement areas and integrated into the denominated mobile toolkits.

Thus, it is observed that within this wide regional variability, the technological behaviour, the composition of the tools and/or the hunting activity does not depend on the different types of habitat. Regardless of climatic conditions and changes, these strategies, both technical and subsistence, are stable and were maintained throughout MIS 5-3. It is the topography of the territory that determines, in part, the type of habitat and the exploitation of the environment, especially its animal resources. In the future, this new type of approach can be improved with new technologies - such as geostatistical, energy cost analysis, the reconstruction of natural pathways - and with new analytics such as dental micro-wear, stable isotopes or dental calculus of the prey obtained.

Acknowledgements Research carried out for this paper has benefited from the following: 'Síntesis del Paleolitico medio y superior en Valencia y Murcia: aspectos cronológicos, paleoambientales, económicos y culturales' (HAR2017-85,153-P/MICINN), 'El pasado lejano: aproximación a la conducta y la ocupación del territorio en el paleolítico valenciano' (PROMETEO/2017/060), 'Snapshots of Neanderthal lifestyles: Behavioural patterns and high resolution archaeology' (HAR2016-76,760-C3-1-P/MICINN) and the Research Group n 2017 SGR 836 of the Catalan Government. AE is supported by a 2018 Leonardo Project for Researchers and Cultural Creators, BBVA Foundation. M.G.CH and M.V research is funded by CERCA (Centres de Recerca de Catalunya) Programme/Generalitat de Catalunya. A.B was supported by a Marie Curie Fellowship PREKARN n.702584.

\section{References}

Álvarez, D. (2014). First Neanderthal settlements in northern Iberia: The Acheulean and the emergence of Mousterian technology in the Cantabrian region. Quaternary International, 326-327, 288-306.

Álvarez, D., \& Arrizabalaga, A. (2012). La secuencia inferior de la cueva de Lezetxiki (Arrasate, País Vasco): Una reflexión necesaria. Zephyrus, LXIX, 15-39.

Andrefsky, W. (1994). Raw material availability and the organization of technology. American Antiquity, 59, 21-34. 
Andrefsky, W. (2009). The analysis of stone tool procurement, production and maintenance. Journal of Archaeological Research, 17, 65-103.

Aparicio, J. (1981). Primeras dataciones de C-14 para el musteriense valenciano. Archivo de Prehistoria Levantina, 16, 9-38.

Arrizabalaga, A., \& Rios, J. (2012). The first human occupation of the Basque crossroads. Journal of World Prehistory, 25, 157-181.

Arsuaga, J. L., Fernández Peris, J., Gracia, A., Quam, R., Carretero, J. M., Barciela, V., et al. (2012). Fossil remains from Bolomor cave (Valencia, Spain). Journal of Human Evolution, 62, 629-639.

Arsuaga, J. L., Villaverde, V., Quam, R., Martínez, I., Carretero, J. M., Lorenzo, C., et al. (2007). New Neandertal remains from Cova Negra (Valencia, Spain). Journal of Human Evolution, 52, 31-58.

Aura, J. E., Fernández Peris, J., \& Fumanal, M. P. (1993). Medio físico y corredores naturales: Notas sobre el poblamiento paleolítico en el País Valenciano. Recerques del Museu d'Alcoi, 2, 89-107.

Aura, J. E., Villaverde, V., Pérez Ripoll, M., Martínez Valle, R., \& Guillem, P. M. (2002). Big game and small prey: Paleolithic and Epipaleolithic economy from Valencia (Spain). Journal of Archaeological Method and Theory, 9, 215-267.

Badal, E., Villaverde, V., \& Zilhão, J. (2012). Middle Paleolithic wood charcoal from three southern Iberian sites: Biogeographic implications. Wood and charcoal. Evidence for human and natural history. Saguntum Extra, 13, 13-24.

Baena, J., Carrión, E., Ruiz, B., Ellwood, B., Sesé, C., Yravedra, J., et al. (2005). Paleoecología y comportamiento humano durante el Pleistoceno Superior en la comarca de Liébana: La secuencia de la Cueva de El Esquilleu (Occidente de Cantabria, España). In J. A. Lasheras \& R. Montes (Eds.), Neandertales Cantábricos: Estado de la cuestión. Monografías del Museo Nacional y Centro de Investigación de Altamira 20 (pp. 461-487). Santander: Museo de Altamira.

Baena, J., Moncel, M. H., Cuartero, F., Chacón, M. G., \& Rubio, D. (2017). Late Middle Pleistocene genesis of Neanderthal technology in Western Europe: The case of Payre site (south-east France). Quaternary International, 436, 51-65.

Barandiarán, I. (1975). Yacimiento musteriense del covacho de Eudoviges (Teruel). Tabona, 3, 7-11.

Bargalló, A., Gabucio, M. J., \& Rivals, F. (2016). Puzzling out a palimpsest: Testing an interdisciplinary study in level O of Abric Romaní. Quaternary International, 417, 51-65.

Barkai, R., Lemorini, C., \& Gopher, A. (2010). Palaeolithic cutlery 400.000-200.000 years ago: Tiny meat-cutting tools from Qesem Cave, Israel. Antiquity, 84, 325.

Beeching, A., \& Gascó, J. (1989). Les foyers de la préhistoire récente du Sud de la France: Descriptions, analyses et essais d'interprétation. In M. Olive \& Y. Taborin (Eds.), Nature et fonction des foyers préhistoriques (pp. 275-292). Nemours: Édition APRAIF.

Binford, L. (1978). Dimensional analysis of behavior and site structure: Learning from an Eskimo hunting stand. American Antiquity, 43, 330-361.

Binford, L. (1982). The archaeology of place. Journal of Anthropological Archaeology, 1, 5-33.

Binford, L. (1983). In pursuit of the past: Decoding the archaeological record. London: Thames \& Hudson.

Blasco, R. (2011). La amplitud de la dieta cárnica en el Pleistoceno medio peninsular: Una aproximación a partir de la Cova del Bolomor (Tavernes de la Valldigna, Valencia) y del subnivel C10-1 de Gran Dolina (Sierra de Atapuerca, Burgos). Unpublished PhD. Dissertation, Universitat Rovira i Virgili, Tarragona.

Blasco, R., \& Fernández Peris, J. (2012). A uniquely broad spectrum diet during the Middle Pleistocene at Bolomor Cave (Valencia, Spain). Quaternary International, 252, 16-31.

Blasco, F., Montes, L., \& Utrilla, P. (1996). Deux modèles de stratégie occupationelle dans le Moustérien tardif de la vallée de l'Ebre: Les grottes de Peña Miel et Gabasa. In E. Carbonell \& M. Vaquero (Eds.), The last Neandertals, the first Anatomically Modern Humans: A tale about the human diversity (pp. 289-313). Tarragona: Universitat Rovira i Virgili.

Boëda, E. (1994). Le concept Levallois: Variabilité des méthodes. CRA-Monographie (Vol. 9). Paris: CNRS.

Boëda, E., Geneste, J. M., \& Meignen, L. (1990). Identification de chaînes opératoires lithiques du Paléolithique ancien et moyen. Paléo, 2, 43-80.

Bordes, F. (1980). Le débitage Levallois et ses variantes. Bulletin de la Société préhistorique française, 77, 45-49.

Bordes, F. (1981). Vingt-cinq ans après: Le complexe moustérien revisité. Bulletin de la Société Préhistorique Française, 78, 77-87. 
Bourguignon, L., Delagnes, A., \& Meignen, L. (2006). Systèmes de production lithique, gestion des outillages et territoire au Paléolithique moyen: Où se trouve la complexité? In L. Astruc, F. Bon, L. Léa, P. Y. Milcent, \& S. Philibert (Eds.), Normes techniques et pratiques sociales: De la simplicité des outillages pré- et protohistoriques. XXVIèmes Rencontres Internationales d'Archéologie et d'Histoire d'Antibes (pp. 75-86). Sophia Antipolis: Éditions APDCA.

Bourguignon, L., Faivre, J. P., \& Turq, A. (2004). Ramification des chaînes opératoires: Une spécificité du moustérien. Paléo, 16, 37-48.

Burke, A. (2006). Neanderthal settlement patterns in Crimea: A landscape approach. Journal of Anthropological Archaeology, 25, 510-523.

Camarós, E., Cueto, M., Lorenzo, C., Villaverde, V., \& Rivals, F. (2016). Large carnivore attacks on hominins during the Pleistocene: A forensic approach with a Neanderthal example. Archaeological and Anthropological Science, 8, 635-646.

Carrión, Y., Guillem, P., Eixea, A., Martínez-Varea, C., Tormo, C., Badal, E., et al. (2019). Climate, environment and human behaviour in the Middle Palaeolithic of Abrigo de la Quebrada (Valencia, Spain): The evidence from charred plant and micromammal remains. Quaternary Science Review, 217, 152-168.

Casabó, J., \& Rovira, M. L. (1992). El Pinar, yacimiento al aire libre con industria sobre lascas del Paleolítico medio. In P. Utrilla (Ed.), Aragón, Litoral Mediterráneo, Intercambios culturales durante la Prehistoria (pp. 89-95). Zaragoza: Institución Fernando el Católico.

Casanova, J., Martínez Moreno, J., Mora, R., \& de la Torre, I. (2009). Stratégies techniques dans le Paléolithique Moyen du sud-est des Pyrénées. L’Anthropologie, 113, 313-340.

Cauche, D. (2002). Les cultures moustériennes en Ligurie italienne: Etude des industries lithiques des grottes de la Madonna dell'Arma, d'Arma delle Manie et de Santa Lucia Superiore. Unpublished $\mathrm{PhD}$. Dissertation, Université de la Méditerranée Aix-Marseille II, Marseille.

Cauche, D. (2007). Les cultures moustériennes en Ligurie italienne: Analyse du matériel lithique de trois sites en grotte. L'Anthropologie, 111, 254-289.

Cauche, D. (2012). Productions lithiques et comportements techno-économiques de groupes humains acheuléens et moustériens en région liguro-provençale. Comptes Rendus Palevol, 11, 519-527.

Chacón, M. G. (2009). The Middle Palaeollithic in southwestern Europe: Abric Romaní (Capellades, Barcelona, Spain), Payre (Rompón, Ardèche, France) and Tournal (Bize, Aude, France). Comparative analysis of the lithic assemblages and the human behaviours. Unpublished $\mathrm{PhD}$. Dissertation, Universitat Rovira i Virgili, Tarragona \& Muséum National d'Histoire Naturelle, Paris.

Chase, P. (1986). The hunters of Combe-Grenal: Approaches to Middle Paleolithic subsistence in Europe. BAR S286. Oxford: British Archaeological Reports.

Chase, P. (1988). Scavenging and hunting in the Middle Paleolithic: The evidence from Europe. In H. Dibble \& A. Montet-White (Eds.), Upper Pleistocene prehistory of western Eurasia (pp. 226-232). Philadelphia: University of Pennsylvania Press.

Conard, N., Bolus, M., \& Münzel, S. C. (2012). Middle Paleolithic land use, spatial organization and settlement intensity in the Swabian Jura, southwestern Germany. Quaternary International, 247, $236-245$.

Connolly, R., Herrera-Herrera, A., Hernández, C. M., Galván, B., \& Mallol, C. (2019). Inferring millennial-scale hydroclimatic variability at the Middle Palaeolithic rock-shelter of Abric del Pastor (S.E. Iberia): Combining leaf wax $\delta 2 \mathrm{H}, \delta 13 \mathrm{C}$ and soil micromorphology. In Prehistoric Adaptations to Cold Environments (PACE): Multidisciplinary approaches, January 8th-9th 2019. Nice: Université Nice Sophia Antipolis.

Cortés, M. (2007). El Paleolítico Medio y Superior en el sector central de Andalucía (Córdoba y Málaga). Santander: Museo Nacional.

Costamagno, S., Meignen, L., Beauval, C., Vandermeersch, B., \& Maureille, B. (2006). Les Pradelles (Marillac-le-Franc, France): A Mousterian reindeer hunting camp? Journal of Anthropological Archaeology, 25, 466-484.

Cuartero, F. (2007). Tecnología lítica en Cova del Bolomor nivel IV. ¿Una economía de reciclado? Saguntum, 39, 27-44.

Daujeard, C., Fernandes, P., Guadelli, J. L., Moncel, M. H., Santagata, C., \& Raynal, J. P. (2012). Neanderthal subsistence strategies in Southeastern France between the plains of the Rhône Valley and the mid-mountains of the Massif Central (MIS 7 to MIS 3). Quaternary International, 252, 32-47. 
Daujeard, C., \& Moncel, M. H. (2010). On Neanderthal subsistence strategies and land use: A regional focus on the Rhône Valley area in southeastern France. Journal of Anthropological Archaeology, 29, 368-391.

Daujeard, C., Vettese, D., Britton, K., Béarez, P., Boulbes, N., Crégut-Bonnoure, E., et al. (2019). Neanderthal selective hunting of reindeer in the Upper Pleistocene of Western Europe: The example of Abri du Maras (Southeastern France, Level 4.1, MIS 3). Anthropological Archaeological Science, 11, 985-1011.

Daura, J., Sanz, M., Julià, R., García-Fernández, D., Fornós, J. J., Vaquero, M., et al. (2015). Cova del Rinoceront (Castelldefels, Barcelona): A terrestrial record for the Last Interglacial period (MIS 5) in the Mediterranean coast of the Iberian Peninsula. Quaternary Science Reviews, 114, 203-227.

Daura, J., Sanz, M., Pike, A., Subirà, M. E., Fornós, J. J., Fullola, J. M., et al. (2010). Stratigraphic context and direct dating of the Neandertal mandible from Cova del Gegant (Sitges, Barcelona). Journal of Human Evolution, 59, 109-122.

David, F., \& Enloe, J. G. (1993). L'exploitation des animaux sauvages de la fin du Paléolithique moyen au Magdalénien. In J. Desse \& F. Audoin-Rouzeau (Eds.), Exploitation des animaux sauvages à travers le temps. XIIIèmes Rencontres Internationales d'Archéologie et d'Histoire d'Antibes (pp. 29-47). Sophia Antipolis: Éditions APDCA.

Delagnes, A., \& Meignen, L. (2006). Diversity of lithic production systems during the Middle Paleolithic in France: Are there any chronological trends? In E. Hovers \& S. Kuhn (Eds.), Transitions before the transition: Evolution and stability in the Middle Paleolithic and Middle Stone Age (pp. 85-107). New York: Springer.

Delagnes, A., \& Rendu, W. (2011). Shifts in Neandertal mobility, technology and subsistence strategies in western France. Journal of Archaeological Science, 38, 1771-1783.

de la Torre, I., Martínez-Moreno, J., \& Mora, R. (2013). Change and stasis in the Iberian Middle Paleolithic: Considerations on the significance of Mousterian technological variability. Current Anthropology, 54, 320-336.

Del Lucchese, A., Martini, S., Negrino, F., \& Ottomano, C. (2001). I Ciotti (Mortola Superiore, Ventimiglia, Imperia): Una località di approvvigionamento della materia prima per la scheggiatura durante il Paleolitico. Bulletino di Paletnologia Italiana, 91-92, 1-26.

d'Errico, F. (2003). The invisible frontier: A multiple species model for the origin of behavioral modernity. Evolutionary Anthropology, 12, 188-202.

Dibble, H., \& Mc Pherron, S. (2006). The missing Mousterian. Current Anthropology, 47, 777-803.

Doménech, E. M. (2005). La transición del Paleolítico medio al superior en la Cova Beneito (Muro, Alicante): Recientes aportaciones. In A. Pérez-González, M. Santonja, \& M. J. Machado (Eds.), Geoarqueología y patrimonio en la Península Ibérica y el entorno mediterráneo (pp. 197-203). Madrid: ADEMA.

Durand, E., Franc, O., Pasty, J. P., Alix, Ph, \& Moncel, M. H. (2009). Le site perché moustérien de la montagne d'Andance (Saint-Bauzile, Ardèche): Première approche archéologique. Ardèche Archéologie, 26, 15-21.

Echassoux, A., d'Errico, F., Giacobini, G., del Lucchese, A., de Lumley, H., de Lumley, M. A., et al. (1989). Les nouvelles fouilles dans le gisement moustérien de la Caverna delle Fate (Finale, Ligurie italienne). In M. Otte (Ed.), L’homme de Néandertal 6 (pp. 49-58). Liège: ERAUL.

Eixea, A. (2012). Aprovechamiento de las calizas en el Paleolítico medio del Abrigo de la Quebrada (Chelva, Valencia) (pp. 53-64). XXIX: Archivo de Prehistoria Levantina.

Eixea, A. (2015). Caracterización tecnológica y uso del espacio en los yacimientos del Paleolítico medio de la región central del Mediterráneo Ibérico. Unpublished PhD. Dissertation, Universitat de València, Valencia.

Eixea, A. (2018). Middle Paleolithic lithic assemblages in Western Mediterranean Europe from MIS 5 to 3. Journal of Archaeological Science. Reports, 21, 643-666.

Eixea, A., Giner, B., Jardón, P., Zilhão, J., \& Villaverde, V. (2015). Elementos líticos apuntados en el yacimiento del Paleolítico medio del Abrigo de la Quebrada: Caracterización tecno-tipológica y análisis de las macrofracturas. Espacio, Tiempo y Forma, 8, 78-109.

Eixea, A., Oltra, I., Bergadà, M., \& Villaverde, V. (2020). The reinterpretation of Cova Negra archaeological and stratigraphical sequence and its implications in the knowledge of the Middle Palaeolithic Iberian Peninsula. Quaternary International. https://doi.org/10.1016/j.quaint.2020.04.007. 
Eixea, A., \& Villaverde, V. (2012). Materiales líticos del Paleolítico medio y superior en el yacimiento de superficie dels Bancals de Pere Jordi (La Vall de Gallinera, Alicante) (pp. 65-79). XXIX: Archivo de Prehistoria Levantina.

Eixea, A., Villaverde, V., Roldán, C., \& Zilhão, J. (2014). Middle Palaeolithic flint procurement in central Mediterranean Iberia: Implications for human mobility. Journal of Lithic Studies, 1, 103-115.

Eixea, A., Villaverde, V., \& Zilhão, J. (2016). Not only flint: Levallois on quartzite and limestone at Abrigo de la Quebrada (Valencia, Spain). Implications for Neandertal Behavior. Journal of Anthropological Research, 72, 24-57.

Eixea, A., Villaverde, V., Zilhão, J., Sanchis, A., Morales, J. V., Real, C., et al. (2011). El nivel IV del Abrigo de la Quebrada (Chelva, Valencia): Análisis microespacial y valoración del uso del espacio en los yacimientos del Paleolítico medio valenciano. Mainake, XXXIII, 127-158.

Fernandes, P., Raynal, J. P., \& Moncel, M. H. (2008). Middle Palaeolithic raw material gathering territories and human mobility in the southern Massif Central, France: First results from a petro-archaeological study on flint. Journal of Archaeological Science, 35, 2357-2370.

Fernández Peris, J. (1994). El Paleolítico inferior en el País Valenciano. Recerques del Museu d'Alcoi, 2, 7-21.

Fernández Peris, J. (1998). La Coca (Aspe, Alicante): Área de aprovisionamiento y talla del Paleolítico medio. Recerques del Museu d'Alcoi, 7, 9-46.

Fernández Peris, J. (2004). Datos sobre la incidencia de carnívoros en la Cova del Bolomor (Tavernes de la Valldigna, Valencia). Miscelánea en homenaje a Emiliano Aguirre (pp. 141-157). Madrid: Museo Arqueológico Regional.

Fernández Peris, J. (2007). La Cova del Bolomor (Tavernes de la Valldigna, Valencia). Serie de Trabajos Varios del SIP 108. Valencia: Diputación de Valencia.

Fernández Peris, J., Barciela, V., Blasco, R., Cuartero, F., \& Sañudo, P. (2008). El Paleolítico Medio en el territorio valenciano y la variabilidad tecno-económica de la Cova del Bolomor. Treballs d'Arqueologia, 14, 141-169.

Fernández Peris, J., \& Martínez Valle, R. (1989). El yacimiento del Paleolítico medio de San Luis (Buñol, Valencia). Saguntum, 22, 11-34.

Fernández, Peris J., \& Villaverde, V. (2001). El Paleolítico medio: El tiempo de los Neandertales. Periodización y características. In V. Villaverde (Ed.), De neandertales a cromañones: El inicio del poblamiento humano en las tierras valencianas (pp. 147-176). Valencia: Universidad de Valencia.

Fiore, I., Gala, M., \& Tagliacozzo, A. (2004). Ecology and subsistence strategies in the Eastern Italian Alps during the Middle Palaeolithic. International Journal of Osteoarchaeology, 14, 273-286.

Fiore, I., Raynal, J. P., \& Tagliacozzo, A. (2005). Archeozoologia e aspetti tafonomici del sito musteriano di Baume-Vallée (Massicio centrale francese). In I. Fiore, G. Malerba, \& S. Chilardi (Eds.), Studi di Paletnologia (pp. 81-92). Roma: Istituto Poligrafico e Zecca dello Stato.

Fiorenza, L., Benazzi, S., Henry, A. G., Salazar-García, D. C., Blasco, R., Picin, A., et al. (2015). To meat or not to meat? New perspectives on Neanderthal ecology. American Journal of Physical Anthropology, 156, 43-71.

Fumanal, M. P. (1995). Los depósitos cuaternarios en cuevas y abrigos: Implicaciones sedimentológicas. El Cuaternario del País Valenciano (pp. 115-124). Valencia: Universitat de València y AEQUA.

Galanidou, N. (2000). Patterns in caves: Foragers, horticulturists and the use of space. Journal of Anthropological Archaeology, 19, 243-275.

Galván, B., Hernández, C., Barroso, V. A., Barro, A., Garralda, M. D., \& Vandermeersch, B. (2001). El Salt (Serra Mariola, Alacant). In V. Villaverde (Ed.), De neandertales a cromañones: El inicio del poblamiento humano en las tierras valencianas (pp. 397-402). Valencia: Universidad de Valencia.

Galván, B., Hernández, C. M., \& Francisco, M. I. (2007). Elementos líticos apuntados en el Musteriense alcoyano: El Abric del Pastor (Alicante). Veleia, 24-25, 367-383.

Galván, B., Hernández, C. M., Francisco, M. I., Molina, F. J., \& Tarriño, A. (2009). La producción lítica del Abric del Pastor (Alcoy, Alicante): Un ejemplo de variabilidad musteriense. Tabona, 17, 11-62.

Galván, B., Hernández, C. M., Mallol, C., Mercier, N., Sistiaga, A., \& Soler, V. (2014). New evidence of early Neanderthal disappearance in the Iberian Peninsula. Journal of Human Evolution, 75, 16-27.

Gamble, C. (1986). The Palaeolithic settlement of Europe. Cambridge: Cambridge University Press.

Gaudzinski, S. (2000). Adults only: Reindeer hunting at the Middle Palaeolithic site Salzgitter Lebsenstedt, Northern Germany. Journal of Human Evolution, 38, 497-521.

Geneste, J. M. (1985). Analyse lithique d'industries moustériennes du Périgord: Une approche technologique du comportement des groupes humains au Paléolithique moyen. Unpublished PhD. Dissertation, Université de Bordeaux I, Bourdeaux. 
Geneste, J. M. (1988). Systèmes d'approvisionnement en matières premières au Paléolithique Moyen et au Paléolithique Supérieur en Aquitaine. In J. K. Kozloswki (Ed.), L’homme de Néandertal 8 (pp. 61-70). Liège: ERAUL.

Geneste, J. M., Jaubert, J., Lenoir, M., Meignen, L., \& Turq, A. (1997). Approche technologique des Moustériens charentiens du sud-ouest de la France et du Languedoc oriental. Paléo, 9, 101-142.

Geneste, J. M., \& Plisson, H. (1996). Production et utilisation de l'outillage lithique dans le Moustérien du Sud-ouest de la France: Les Tares à Sourzac, vallée de l'Isle, Dordogne. Quaternaria Nova, 6, $149-166$.

González-Urquijo, J., \& Ibáñez, J. J. (1994). Metodología de análisis funcional de instrumentos tallados en sílex. Cuadernos de Arqueología 14. Bilbao: Universidad de Deusto.

Goren Inbar, N. (1988). Too small to be true? Reevaluation of cores on flakes in Levantine Mousterian assemblages. Lithic Technology, 17, 37-44.

Grayson, D. K., \& Delpech, F. (2002). Specialized early Upper Palaeolithic hunters in Southwestern France? Journal of Archaeological Science, 29, 1439-1449.

Grimaldi, S., \& Santaniello, F. (2014). New insights into Final Mousterian lithic production in western Italy. Quaternary International, 350, 116-129.

Gusi, F., Olària, C., Ollé, A., Saladié, P., Vallverdú, J., Cáceres, I., et al. (2013). La Cova de Dalt del Tossal de la Font (Vilafamés, Castellón): Conclusiones preliminares de las intervenciones arqueológicas (1982). Quaderns de prehistòria i arqueologia de Castelló, 31, 17-37.

Hardy, B. L., Moncel, M. H., Daujeard, C., Fernandes, P., Béarez, P., Desclaux, E., et al. (2013). Impossible Neanderthals? Making string, throwing projectiles and catching small game during Marine Isotope Stage 4 (Abri du Maras, France). Quaternary Science Reviews, 82, 23-40.

Haws, J., Benedetti, M., Funk, C., Bicho, N., Pereira, T., Marreiros, J., et al. (2020). Late Pleistocene landscape and settlement dynamics of Portuguese Estremadura. Journal of Field Archaeology, 45, $222-248$.

Hernández, C., Galván, B., Mallol, C., Machado, J., Molina, F. J., Pérez, L., et al. (2014). Abric de El Pastor in the Neanderthal occupation of the Alcoy valleys, Alicante (Spain). In E. Carbonell, J. M. Bermúdez de Castro, \& J. L. Arsuaga (Eds.), Pleistocene and Holocene hunter-gatherers in Iberia and the Gibraltar Strait: The current archaeological record (pp. 319-323). Burgos: Fundación Atapuerca y Universidad de Burgos.

Hiscock, P. (2009). Reduction, recycling and raw material procurement in Western Arnhem Land, Australia. In B. Adams \& B. Blades (Eds.), Lithic materials and Paleolithic societies (pp. 78-93). Oxford: Willey.

Isetti, G., de Lumley, H., \& Miskovsky, J. C. (1962). Il giacimento musetriano della Grotta dell'Arma presso Bussana (Sanremo). Rivista di Studi Liguri, 1-4, 5-116.

Iturbe, G. (1991). Cova Beneito (Muro del Comtat-Alicante) y su aportación al conocimiento del Paleolítico Medio y Superior del Levante español. Unpublished PhD. Dissertation, Universidad de Zaragoza, Zaragoza.

Iturbe, G., \& Cortell, E. (1987). Las dataciones de Cova Beneito y su interés para el Paleolítico mediterráneo. Trabajos de Prehistoria, 44, 267-270.

Iturbe, G., Fumanal, M. P., Carrión, J., Cortell, E., Martínez, R., Guillem, P., et al. (1993). Cova Beneito (Muro, Alicante): Una perspectiva interdisciplinar. Recerques del Museu d'Alcoi, 2, 23-88.

Jaubert, J., \& Farizy, C. (1995). Levallois débitage: Exclusivity, absence or coexistence with other operative schemes in the Garonne Basin, southwestern France. In H. Dibble \& O. Bar-Yosef (Eds.), The definition and interpretation of Levallois technology (pp. 227-248). Madison: Prehistory Press.

Jaubert, J., \& Mourre, V. (1996). Coudoulous, Le Rescoundudou, Mauran: Diversité des matières premières et variabilité des schémas de production d'éclats. Quaternaria Nova, 6, 313-341.

Kent, S. (1987). Method and theory for activity area research: An ethnoarchaeological approach. New York: Columbia University Press.

Kitagawa, K., Krönneck, P., Conard, N., \& Münzel, S. C. (2012). Exploring cave use and exploitation among cave bears, carnivores and hominins in the Swabian Jura, Germany. Journal of Taphonomy, 10, 439-461.

Klasen, N. (2015). OSL dating of sediment samples from Spain by order of SFB 806, subproject C1 (series Quebrada). Unpublished report.

Koumouzelis, M., Kozlowski, J., Escutenaire, C., Sitlivy, V., Sobczyk, K., Valladas, H., et al. (2001). La fin du Paléolithique moyen et le début du Paléolithique supérieur en Grèce: La séquence de la Grotte 1 de Klissoura. L'Anthropologie, 105, 469-504. 
Kuhn, S., \& Elston, R. (2002). Thinking small globally. In R. Elston \& S. Kuhn (Eds.), Thinking small: Global perspectives on microlithization (pp. 1-7). Mississippi: Archeological Papers of the American Anthropological Association.

Kuhn, S., \& Stiner, M. (1992). New research at Riparo Mochi, Balzi Rossi (Liguria): Preliminary results. Quaternaria Nova, II, 77-90.

Larson, M. L., \& Ingbar, E. E. (1992). Perspectives on refitting: Critique and a complementary approach. In J. Hofman \& J. Enloe (Eds.), Piecing together the past: Applications of refitting studies in archaeology. BAR International Series (pp. 21-35). Oxford: British Archaeological Reports.

Lebègue, F. (2012). Le Paléolithique moyen récent entre Rhône et Pyrénées: Approche de l'organisation techno-économique des productions lithiques, schémas de mobilité et organisation du territoire (Les Canalettes, L'Hortus, Bize-Tournal, La Crouzade et La Roquette II). Unpublished PhD. Dissertation, Université de Perpignan, Perpignan.

Leierer, L., Jambrina-Enríquez, M., Herrera-Herrera, A., Connolly, R., Hernández, C. M., Galván, B., et al. (2019). Insights into the timing, intensity and natural setting of Neanderthal occupation from the geoarchaeological study of combustion structures: A micromorphological and biomarker investigation of El Salt, unit Xb, Alcoy, Spain. PLoS ONE, 14, e0214955.

Lenoir, M., \& Turq, A. (1995). Recurrent centripetal debitage (Levallois and discoidal): Continuity or discontinuity? In H. Dibble \& O. Bar-Yosef (Eds.), The definition and interpretation of Levallois technology (pp. 249-256). Madison: Prehistory Press.

Lumley, H. (1971). Le Paléolithique inférieur et moyen dans son cadre géologique. T. II, Bas Languedoc - Roussillon - Catalogne. V Supplément Gallia Préhistoire. Paris: Presse du CNRS.

Machado, J., Hernández, C. M., \& Galván, B. (2011). Contribución teórico-metodológica al análisis histórico de palimpsestos arqueológicos a partir de la producción lítica: Un ejemplo de aplicación para el Paleolítico medio en el yacimiento de El Salt (Alcoy, Alicante). Recerques del Museu d'Alcoi, 20, 33-46.

Machado, J., Hernández, C. M., Mallol, C., \& Galván, B. (2013). Lithic production, site formation and Middle Palaeolithic palimpsest analysis: In search of human occupation episodes at Abric del Pastor stratigraphic Unit IV (Alicante, Spain). Journal of Archaeological Science, 20, 2254-2273.

Machado, J., Mallol, C., \& Hernández, C. M. (2015). Insights into Eurasian Middle Palaeolithic settlement dynamics: The palimpsest problem. In N. Conard \& A. Delagnes (Eds.), Settlement dynamics of the Middle Paleolithic and Middle Stone Age (pp. 361-382). Tübingen: Kerns Verlag.

Machado, J., Molina, F. J., Hernández, C. M., Tarriño, A., \& Galván, B. (2017). Using lithic assemblage formation to approach Middle Palaeolithic settlement dynamics: El Salt Stratigraphic Unit X (Alicante, Spain). Archaeological and Anthropological Science, 9, 1715-1743.

Machado, J., \& Pérez, L. (2016). Temporal frameworks to approach human behavior concealed in Middle Palaeolithic palimpsests: A high-resolution example from El Salt Stratigraphic Unit X (Alicante, Spain). Quaternary International, 417, 66-81.

Magniez, P. (2010). Etude paléontologique des Artiodactyles de la grotte Tournal: Etude taphonomique, archéozoologique et paléoécologique des grands mammifères dans leur cadre biostratigraphique et paléoenvironnemental. Unpublished PhD. Dissertation, Université Via Domitia, Perpignan.

Mallol, C., Hernández, H., Mercier, N., Falguères, C., Carrancho, A., Cabanes, D., et al. (2019). Fire and brief human occupations in Iberia during MIS 4: Evidence from Abric del Pastor (Alcoy, Spain). Scientific Reports, 9, 18281.

Marín, J., Rodríguez-Hidalgo, A., Vallverdú, J., Gómez de Soler, B., Rivals, F., Rabuñal, J., et al. (2019). Neanderthal logistic mobility during MIS3: Zooarchaeological perspective of Abric Romaní Level P (Spain). Quaternary Science Reviews, 225, 106033.

Marks, A., Monigal, K., \& Zilhão, J. (2001). The lithic assemblages of the Late Mousterian at Gruta da Oliveira, Almonda, Portugal. In J. Zilhão, T. Aubry, \& A. F. Carvalho (Eds.), Les premiers hommes modernes de la Péninsule Ibérique (pp. 145-154). Lisboa: Instituto Português de Arqueologia.

Marín, J., Daujeard, C., Saladié, P., Rodríguez-Hidalgo, A., Vetesse, D., Rivals, F., et al. (2020). Neanderthal faunal exploitation and settlement dynamics at the Abri du Maras, level 5 (south-eastern France). Quaternary Science Reviews, 243, 106472.

Maroto, J., Julià, R., López-García, J. M., \& Blain, H. A. (2012). Chronological and environmental context of the Middle Pleistocene human tooth from Mollet Cave (Serinyà, NE Iberian Peninsula). Journal of Human Evolution, 62, 655-663.

Maroto, J., Soler, N., \& Fullola, J. M. (1996). Cultural change between Middle and Upper Paleolithic in Catalonia. In E. Carbonell \& M. Vaquero (Eds.), The last Neandertals, the first Anatomically 
Modern Humans: A tale about the human diversity (pp. 219-250). Tarragona: Universitat Rovira i Virgili.

Marrero, E., Hernández, C. M., \& Galván, B. (2011). El análisis espacial en el estudio de las secuencias de facies arqueosedimentarias: Criterios para identificar eventos de ocupación en yacimientos del Paleolítico Medio: El Salt y el Abric del Pastor (Alcoy, Alicante, España). Recerques del Museu d'Alcoi, 20, 7-32.

Martínez-Moreno, J., Mora, R., \& de la Torre, I. (2010). The Middle-to-Upper Palaeolithic transition in Cova Gran (Catalunya, Spain) and the extinction of Neanderthals in the Iberian Peninsula. Journal of Human Evolution, 58, 211-226.

Martínez Valle, R. (1996). Fauna del Pleistoceno superior en el País Valenciano: Aspectos económicos, huella de manipulación y valoración paleoambiental. Unpublised PhD. Dissertation, Universitat de València, Valencia.

Martínez Valle, R. (2009). Restos óseos de macromamíferos y aves. In V. Villaverde, J. Pérez Ballester, \& A. Ledo (Eds.), Historia de Xàtiva: Prehistoria, Arqueología y Antigüedad (pp. 59-83). Xàtiva: Universitat de València.

Martínez Valle, R., Guillem, P., \& Villaverde, V. (2016). Bird consumption in the final stage of Cova Negra (Xátiva, Valencia). Quaternary International, 421, 85-102.

Mayor, A., Hernández, C. M., Machado, J., Mallol, C., \& Galván, B. (2020). On identifying Palaeolithic single occupation episodes: Archaeostratigraphic and technological approaches to the Neanderthal lithic record of stratigraphic unit Xa of El Salt (Alcoi, eastern Iberia). Archaeological and Anthropological Sciences, 12, 84.

Meignen, L. (1988). Une exemple de comportement technologique différentiel selon les matières premières: Marillac, couches 9 et 10. In J. K. Kozloswki (Ed.), L'homme de Néandertal 8 (pp. 71-79). Liège: ERAUL.

Mochales, R. M. (1997). El asentamiento musteriense en el territorio valenciano. Archivo de Prehistoria Levantina, 22, 11-40.

Moles, V. (2008). Etude techno-économique et typologique des industries lithiques de la grotte des Ramandils (Port-la-Nouvelle, Aude, France): Contribution à la reconnaissance d'une microproduction au Paléolithique moyen. Unpublished PhD. Dissertation, Université Montpellier, Montpellier.

Moles, V., \& Boutié, P. (2009). Contribution à la reconnaissance d'une microproduction au Paléolithique moyen: Les industries de la grotte des Ramandils (Port-La Nouvelle, Aude, France). L'Anthropologie, 113, 356-380.

Molina, F. J. (2016). El sílex del Prebético y cuencas Neógenas en Alicante y sur de Valencia: Su caracterización y estudio aplicado al Paleolítico medio. Unpublished PhD. Dissertation, Universitat d'Alacant, Alicante.

Moncel, M. H. (1998). Les niveaux moustériens de la grotte Saint-Marcel (Ardèche): Fouilles R. Gilles. Reconnaissance de niveaux à débitage discoïde dans la vallée du Rhône. Bulletin de la Société Préhistorique Française, 95, 141-171.

Moncel, M. H. (2003). L'exploitation de l'espace et la mobilité des groupes humains au travers des assemblages lithiques à la fin du Pléistocène moyen et au début du Pléistocène supérieur (p. S1184). Oxford: British Archaeological Reports.

Moncel, M. H. (2008). Le site de Payre: Occupations humaines dans la vallée du Rhône à la fin du Pléistocène moyen et au début du Pléistocène supérieur. Paris: Mémoire de la Société Préhistorique Française XLVI.

Moncel, M. H., Allué, E., Bailon, S., Barshay-Szmidt, C., Béarez, Ph, Crégut, E., et al. (2015). Evaluating the integrity of palaeoenvironmental and archaeological records in MIS 5 to 3 karst sequences from southeastern France. Quaternary International, 378, 22-39.

Moncel, M. H., Chacón, M. G., La Porta, A., Fernandes, P., Hardy, B. L., \& Gallotti, R. (2014). Fragmented reduction processes: Middle Palaeolithic technical behaviour in the Abri du Maras shelter, southeastern France. Quaternary International, 350, 180-204.

Moncel, M. H., Daujeard, C., Crégut-Bonnoure, E., Fernandez, P., Faure, M., \& Guérin, C. (2004). L'occupation de la grotte de Saint-Marcel (Ardèche, France) au lithique moyen: Stratégie d'exploitation de l'environnement et type d'occupation de la grotte. L'exemple des couches i, j et j'. Bulletin de la Société Préhistorique Française, 101, 257-304.

Mora, R., de la Torre, I., \& Martínez, J. (2004). Middle Palaeolithic mobility and land use in the southwestern Pyrenees: The example of Level 10 in La Roca dels Bous (Noguera, Catalunya, northeast Spain). In N. Conard (Ed.), Settlement dynamics of the Middle Palaeolithic and Middle Stone Age II (pp. 415-435). Tübingen: Kerns Verlag. 
Mora, R., Martínez-Moreno, J., \& Casanova, J. (2008). Abordando la noción de 'variabilidad musteriense' en Roca dels Bous (Prepirineo suroriental, Lleida). Trabajos de Prehistoria, 65, 13-28.

Morales, J. V., \& Sanchis, A. (2009). The quaternary fossil record of the genus Testudo in the Iberian Peninsula: Archaeological implications and diachronic distribution in the western Mediterranean. Journal of Archaeological Science, 36, 1152-1162.

Mourre, V. (2003). Discoïde ou pas discoïde? Réflexions sur la pertinence des critères techniques définissant le débitage discoïde. In M. Peresani (Ed.), Discoid Lithic technology: Advances and implications (pp. 1-18). Oxford: Archaeopress.

Mourre, V., \& Thiébaut, V. (2008). L'industrie lithique du Moustérien final de la Grotte du Noisetier (Fréchet-Aure, Hautes-Pyrénées) dans le contexte des Pyrénées centrales françaises. Treballs d'Arqueologia, 14, 87-104.

Mussi, M. (2002). Earliest Italy: An overview of the Italian Paleolithic and Mesolithic. New York: Kluwer Academic.

Negrino, F., \& Riel-Salvatore, J. (2018). From Neanderthals to Anatomically Modern Humans in Liguria (Italy): The current state of knowledge. In V. Borgia \& E. Cristiani (Eds.), Palaeolithic Italy: Advanced studies on early human adaptations in the Apennine Peninsula (pp. 161-182). Leiden: Sidestone Press Academics.

Negrino, F., Starnini, E., \& Bertola, S. (2016). Red radiolarite availability in Western Liguria? A challenging enigma from Ortovero (Savona, Liguria, Italy). In A. Tomasso, D. Binder, G. Martino, G. Porraz, P. Simon, \& N. Naudinot (Eds.), Ressources lithiques, productions et transferts entre Alpes et Méditerranée (pp. 45-53). Paris: Séances de la Société préhistorique française.

Negrino, F., \& Tozzi, C. (2008). Il Paleolitico in Liguria. Bulletin du musée d'Anthropologie préhistorique de Monaco, supplement, 1, 21-28.

O'Regan, H. J. (2008). The Iberian Peninsula-corridor or cul-de-sac? Mammalian faunal change and possible routes of dispersal in the last 2 million years. Quaternary Science Review, 27, 2136-2144.

Palma di Cesnola, A. (2001). Il Paleolitico inferiore e medio in Italia. Firenze: Museo Fiorentino di Preistoria 'Paolo Graziosi'.

Parry, W. A., \& Kelly, R. L. (1987). Expedient technology and sedentism. In J. K. Johnson \& C. A. Morrow (Eds.), The organization of core technology (pp. 285-304). Boulder: Westview Press.

Patou-Mathis, M. (1992). La subsistance chez les néandertaliens de Bize (Aude). L’Anthropologie, 1, 113-120.

Patou-Mathis, M. (2000). Neanderthal subsistence behaviours in Europe. International Journal of Osteoarchaeology, 10, 379-395.

Pérez, L. (2014). La gestión de los recursos animales en los Valles de Alcoy durante el Pleistoceno Superior (MIS 3): Estudio zooarqueológico y tafonómico. Unpublished Master Dissertation, Universitat Rovira i Virgili, Tarragona.

Pérez, L. (2015). Aproximación experimental a los indicadores de desocupación humana en yacimientos del Pleistoceno superior a partir de los restos termoalterados de conejos. In A. Sanchis \& J. L. Pascual (Eds.), Preses petites i grups humans en el passat (pp. 27-46). Valencia: Museu de Prehistòria de València.

Pérez, L., Sanchis, A., Hernández, C. M., \& Galván, B. (2017). Paleoecología de macromamíferos aplicada a los conjuntos zooarqueológicos de El Salt y el Abric del Pastor (Alcoy, Alicante). In A. Sanchis \& J. L. Pascual (Eds.), Interaccions entre felins i humans (pp. 327-354). Valencia: Museu de Prehistòria de València.

Pérez Ripoll, M. (1977). Los mamíferos del yacimiento musteriense de Cova Negra. Serie de Trabajos Varios del SIP 53. Valencia: Diputación de Valencia.

Pérez Ripoll, M. (1992). Marcas de carnicería, fracturas intencionadas y mordeduras de carnívoros en huesos prehistóricos del Mediterráneo español. Alicante: Instituto de Cultura Juan Gil-Albert.

Pérez Ripoll, M., Morales, J. V., Sanchis, A., Aura, J. E., \& Sarrión, I. (2010). Presence of the genus Cuon in Upper Pleistocene and Initial Holocene sites of the Iberian Peninsula: New remains identified in archaeological contexts of the Mediterranean region. Journal of Archaeological Science, 37, 437-450.

Pérez Ripoll, M., \& Villaverde, V. (2015). Papel de lepóridos en el Paleolítico de la región central mediterránea ibérica: Valoración de los datos disponibles de los modelos interpretativos. In A. Sanchis \& J. L. Pascual (Eds.), Preses petites i grups humans en el passat (pp. 75-96). Valencia: Museu de Prehistòria de València.

Perlès, C. (1976). Le feu. In H. Lumley (Ed.), La préhistoire française. Tome I: Les civilisations paléolithiques et mésolithiques de la France (pp. 679-683). Paris: CNRS. 
Plisson, H. (1985). Étude fonctionnelle d'outillages lithiques préhistoriques par l'analyse des microusures: Recherche méthodologique et archéologique. Unpublished Thèse de 3e cycle Dissertation, Université de Paris I, Paris.

Plisson, H. (1986). Analyse des polis d'utilisation sur la quartzite. Early Man News, 9(10/11), 47-50.

Porraz, G., \& Negrino, F. (2008). Espaces économiques et approvisionnement minéral au Paléolithique moyen dans l'aire liguro-provençale. Bulletin du musée d'Anthropologie préhistorique de Monaco, supplement, 1, 29-39.

Raynal, J. P., Moncel, M. H., Fernandes, P., Bindon, P., Daujeard, C., Fiore, I., et al. (2013). Land-use strategies, related tool-kits and social organization of Lower and Middle Palaeolithic Groups in the south-east of the Massif Central, France. Quartär, 60, 29-59.

Raynal, J. P., Moncel, M. H., Fernandes, P., Santagata, C., Guadelli, J. L., Fernandez, P., et al. (2008). Espace minéral et espace de subsistance au Paléolithique moyen dans le sud du Massif central en France: Les sites de Sainte-Anne I (Haute-Loire) et de Payre (Ardèche). In M. H. Moncel, A. M. Moigne, M. Arzarello, \& C. Peretto (Eds.), Raw material supply areas and good supply areas: Integrated approach of the behaviours (pp. 141-161). Oxford: Archaeopress.

Real, C., Eixea, A., Sanchis, A., Morales, J. V., Klasen, N., Zilhão, J., et al. (2020). Abrigo de la Quebrada Level IV (Valencia, Spain): Interpreting a Middle Palaeolithic palimpsest from a zooarchaeological and lithic perspective. Journal of Palaeolithic Archaeology, 3, 187-224.

Rendu, W. (2007). Planification des activités de subsistance au sein du territoire des derniers Moustériens: Cémentochronologie et approche archéozoologique de gisements du Paléolithique moyen (Pech-de-l'Azé I, La Quina, Mauran) et Paléolithique supérieur ancien (Isturitz). Unpublished PhD. Dissertation, Université de Bordeaux I, Bourdeaux.

Richard, M., Falgueres, C., Pons-Branchu, E., Bahain, J. J., Voinchet, P., Lebon, M., et al. (2015). Contribution of ESR/U-series dating to the chronology of late Middle Palaeolithic sites in the middle Rhône valley, Southeastern France. Quaternary Geochronology, 30, 529-534.

Richard, M., Falguères, C., Pons-Branchu, E., Foliot, L., Guillem, P. M., Martínez-Valle, R., et al. (2019). ESR/U-series chronology of early Neanderthal occupations at Cova Negra (Valencia, Spain). Quaternary Geochronology, 49, 283-290.

Richter, D., Mercier, N., Valladas, H., Jaubert, J., Texier, J., Brugal, J. P., et al. (2007). Thermoluminescence dating of heated flint from the Mousterian site of Bérigoule, Murs, Vaucluse, France. Journal of Archaeological Science, 34, 532-539.

Rios, J. (2010). Organización económica de las sociedades neandertales: El caso del nivel VII de Amalda (Zestoa, Gipuzkoa). Zephyrus, LXV, 15-37.

Rios, J. (2017). A new chronological and technological synthesis for Late Middle Paleolithic of the Eastern Cantabrian Region. Quaternary International, 433, 50-63.

Rios, J., Eixea, A., \& Villaverde, V. (2014). Ramification of lithic production and the search of small tools in Iberian Peninsula Middle Paleolithic. Quaternary International, 361, 188-199.

Rios, J., Garate, D., Gómez, A., Iriarte, E., Aramburu, A., Arceredillo, D., García, A., Iriarte, M. J., Moreno, J., Murelaga, X., Ortiz, J. E., Torres, T., San Pedro, Z., \& Zapata-Peña, L. (2011). The Lower to Middle Palaeolithic transition in northern Iberia: New data from Arlanpe Cave. Antiquity, 85. http://antiquity.ac.uk/projgall/riosgaraizar329.

Rios, J., \& García, A. (2015). Middle Paleolithic mobility patterns and settlement system variability in the eastern Cantabrian region (Iberian Peninsula): A GIS-based resource patching model. In N. Conard \& A. Delagnes (Eds.), Settlement dynamics of the Middle Paleolithic and Middle Stone Age (pp. 329-360). Tübingen: Kerns Verlag.

Rivals, F., Moncel, M. H., \& Patou-Mathis, M. (2009). Seasonality and intra-site variation of Neanderthal occupations in the Middle Palaeolithic locality of Payre (Ardèche, France) using dental wear analyses. Journal of Archaeological Science, 36, 1070-1078.

Roebroeks, W. (1988). From find scatters to early hominid behaviour: A study of Middle Palaeolithic riverside settlements at Maastricht-Belvédère (The Netherlands). Analecta Praehistorica Leidensia, 21, Leiden.

Romagnoli, F., Baena, J., \& Sarti, L. (2016a). Neanderthal retouched shell tools and Quina economic and technical strategies: An integrated behaviour. Quaternary International, 407, 29-44.

Romagnoli, F., Gómez de Soler, B., Bargalló, A., Chacón, M. G., \& Vaquero, M. (2018). Here and now or a previously planned strategy? Rethinking the concept of ramification for micro-production in expedient contexts: Implications for Neanderthal socio-economic behavior. Quaternary International, 474, 168-181. 
Romagnoli, F., Trenti, F., Nannini, L., Carmignani, L., Ricci, G., Lo Vetro, D., et al. (2016b). Raw-material procurement and productive sequences in the Palaeolithic of southern Italy: The Tyrrhenian and Ionian Areas. In A. Tomasso, D. Binder, G. Martino, G. Porraz, P. Simon, \& N. Naudinot (Eds.), Ressources lithiques, productions et transferts entre Alpes et Méditerranée (pp. 185-205). Paris: Séances de la Société préhistorique française.

Rosell, J., Blasco, R., Fernández-Laso, M. C., Vaquero, M., \& Carbonell, E. (2012). Connecting areas: Faunal refits as a diagnostic element to identify synchronicity in the Abric Romaní archaeological assemblages. Quaternary International, 252, 56-67.

Rosell, J., Blasco, R., Rivals, F., Chacón, M. G., Arilla, M., Camarós, E., et al. (2017). A resilient landscape at Teixoneres Cave (MIS 3; Moià, Barcelona, Spain): The Neanderthals as disrupting agent. Quaternary International, 435, 195-210.

Rosell, J., Huguet, R., Aimene, M., Angelucci, D., Canals, A., Pastó, I., \& Rodríguez Alvarez, X. P. (2000). El yacimiento de las Fuentes de San Cristóbal (Veracruz, Huesca): Un nuevo enclave del Paleolítico Medio en el Prepirineo. In Actas do $3^{\circ}$ Congresso de Arqueologia Peninsular. Vol. II. Paleolítico da Península Ibérica (pp. 235-249). Porto: ADECAP.

Rossoni-Notter, E., Notter, O., \& Simon, P. (2017). Mousterian in Balzi Rossi (Ventimiglia, Liguria, Italy): New insights and old collections. Quaternary International, 435, 21-57.

Sala, N., Algaba, M., Arsuaga, J. L., Aranburu, A., \& Pantoja, A. (2012). A taphonomic study of the Búho and Zarzamora caves: Hyenas and humans in the Iberian plateau (Segovia, Spain) during the Late Pleistocene. Journal of Taphonomy, 10, 477-497.

Salazar-García, D. C., Power, R. C., Sanchis, Serra A., Villaverde, V., Walker, M. J., \& Henry, A. G. (2013). Neanderthal diets in central and southeastern Mediterranean Iberia. Quaternary International, 318, 3-18.

Sanchis, A. (2010). Los lagomorfos del Paleolítico medio de la región central y sudoriental del Mediterráneo ibérico. Caracterización tafonómica y taxonómica. Unpublished PhD. Dissertation, Universitat de València, Valencia.

Sanchis, A. (2012). Los lagomorfos del Paleolítico medio en la vertiente mediterránea ibérica. Humanos y otros predadores como agentes de aporte y alteración de los restos óseos en yacimientos arqueológicos. Serie de Trabajos Varios del SIP 115. Valencia: Diputación de Valencia.

Sanchis, A., Morales, J. V., Pérez, L., Hernández, C., \& Galván, B. (2015a). La tortuga mediterránea en yacimientos valencianos del Paleolítico medio: distribución, origen de las acumulaciones y nuevos datos procedentes del Abric de del Pastor (Alcoi, Alacant). In A. Sanchis \& J. L. Pascual (Eds.), Preses petites i grups humans en el passat (pp. 97-120). Valencia: Museu de Prehistòria de València.

Sanchis, A., Morales, J. V., Real, C., Eixea, A., Zilhão, J., \& Villaverde, V. (2013). Los conjuntos faunísticos del Paleolítico medio del Abrigo de la Quebrada (Chelva, Valencia): Problemática del estudio, metodología aplicada y síntesis de los primeros resultados. In A. Sanchis \& J. L. Pascual (Eds.), Animals i Arqueologia Hui (pp. 65-82). Valencia: Museu de Prehistoria de Valencia.

Sanchis, A., Real, C., Pérez Ripoll, M., \& Villaverde, V. (2016). El conejo en la subsistencia humana del Paleolítico superior inicial en la zona central del Mediterráneo ibérico. In L. Lloveras, C. Rissech, J. Nadal, \& J. M. Fullola (Eds.), What bones tell/El que ens expliquen els ossos (pp. 145-154). Barcelona: Monografies del SERP.

Sanchis, A., Real, C., Sauqué, V., Núñez-Lahuerta, C., Égüez, N., Tormo, C., et al. (2019). Neanderthal and carnivore activities at Llonin Cave, Asturias, northern Iberian Peninsula: Faunal study of Mousterian levels (MIS 3). Comptes Rendus Palevol, 18, 113-141.

Sanchis, A., Tormo, C., Sauqué, V., Sanchis, V., Díaz, R., Ribera, A., et al. (2015b). Pleistocene leopards in the Iberian Peninsula: New evidence from palaeontological and archaeological contexts in the Mediterranean region. Quaternary Science Reviews, 124, 175-208.

Santagata, C. (2012). L'utilisation de roches autres que le silex au Paléolithique ancien et moyen: Choix économiques, techniques et fonctionnels, sur la base de l'étude des gisements de Sainte-Anne I (Haute-Loire, France) (MIS 5 et 6) et de Notarchirico (Basilicata, I ta 1 ia) (MIS 14 à 17). Unpublished PhD. Dissertation, Université de Bordeaux \& Université La Sapienza, Bordeaux \& Roma.

Santamaría, D. (2012). La transición del Paleolítico medio al superior en Asturias: El Abrigo de La Viña (La Manza-neda, Oviedo) y la Cueva de El Sidrón (Borines, Piloña). Unpublished PhD. Dissertation, Universidad de Oviedo, Oviedo.

Sañudo, P., Blasco, R., \& Fernández Peris, J. (2015). Site formation dynamics and human occupations at Bolomor Cave (Valencia, Spain): An archaeostratigraphic analysis of Levels I to XII (100-200 ka). Quaternary International, 417, 94-104. 
Sañudo, P., \& Fernández Peris, J. (2007). Análisis espacial del nivel IV de la Cova del Bolomor (La Valldigna, Valencia). Saguntum, 39, 9-26.

Sanz, M., Daura, J., Égüez, N., \& Brugal, J. P. (2016). Not only hyenids: A multi-scale analysis of Upper Pleistocene carnivore coprolites in Cova del Coll Verdaguer (NE Iberian Peninsula). Palaeogeography, Palaeoclimatology, Palaeoecology, 443, 249-262.

Saos, Th. (2017). Le monde moustérien méditerranéen entre Rhône et Pyrénées. Rapport 2016 du Programme Collectif de Recherche. Bilan triennal 2014-2016.

Sarrión, I. (1990). El yacimiento del Pleistoceno medio de la Cova del Corb (Ondara, Alicante) (pp. 43-78). XX: Archivo de Prehistoria Levantina.

Sauqué, V., \& Cuenca-Bescós, G. (2013). The Iberian Peninsula, the last European refugium of Panthera pardus Linnaeus 1758 during the Upper Pleistocene. Quaternair, 24, 35-48.

Sauqué, V., \& Sanchis, A. (2017). Leopards as taphonomic agents in the Iberian Pleistocene: The case of Racó del Duc (Valencia, Spain). Palaeogeography, Palaeoclimatology, Palaeoecology, 472, 67-82.

Sauqué, V., Sanchis, A., \& Madurell-Malapeira, J. (2018). Late Pleistocene leopards as a bone accumulator: Taphonomic results from S'Espasa cave and other Iberian key sites. Historical Biology, 30, 821-834.

Slimak, L. (1998). La variabilité des débitages discoïdes au Paléolitique Moyen. Préhistoire Anthropologie Méditerranéennes, 7-8, 75-88.

Slimak, L. (2003). Les débitages discoïdes moustériens : Évaluation d'un concept technologique. In M. Peresani (Ed.), Discoid lithic technology: Advances and implications (pp. 33-62). Oxford: Archaeopress.

Soler, B. (2003). Estudio de las estructuras de combustión prehistóricas: Una propuesta experimental. Cova Negra (Xàtiva, Valencia), Ratlla del Bubo (Crevillente, Alicante) y Marolles-sur-Seine (Bassin Parisien, Francia). Serie de Trabajos Varios del SIP 102. Valencia: Diputación de Valencia.

Stapert, D. (1990). Middle Palaeolithic dwellings: Fact or fiction? Some applications of the ring and sector method. Palaeohistoria, 32, 1-19.

Szmidt, C. (2003). The Mousterian in Mediterranean France: A regional, integrative and comparative perspective. Oxford: British Archaeological Reports, S1147.

Tavoso, A. (1987). Le Moustérien de la grotte Tournal. Cypsela, VI, 161-174.

Tavoso, A. (1988). L'outillage du gisement de San Francesco à San Remo (Ligurie, Italie) : Nouvel examen. In J. K. Kozloswki (Ed.), L’homme de Néandertal 8 (pp. 193-210). Liège: ERAUL.

Terradas, X. (2003). Discoid flaking method: Conception and technological variability. In M. Peresani (Ed.), Discoid lithic technology: Advances and implications (pp. 19-31). Oxford: Archaeopress.

Terradas, X., \& Rueda, J. M. (1998). Grotte 120 : Un exemple des activités de subsistance au Paléolithique moyen dans les Pyrénées orientales. In J. P. Brugal, L. Meignen, \& M. Patou-Mathis (Eds.), Économie préhistorique : Les comportements de subsistance au Paléolithique (pp. 349-362). Éditions APDCA: Sophia Antipolis.

Testu, A. (2006). Etude paléontologique et biostratigraphique des Felidae et des Hyaenidae pléistocènes de l'Europe méditerranéenne (sites de la Caune de l'Arago, Orgnac 3, le Portel-Ouest, Bize-Tournal, l'Hortus, la Crouzade en France, la Cova de l'Arbreda en Espagne, Karaïn E en Turquie). Unpublished PhD. Dissertation, Université de Perpignan, Perpignan.

Thiébaut, C., Mourre, V., Chalard, P., Cologne, D., Coudenneau, A., Deschamps, M., et al. (2012). Lithic technology of the final Mousterian on both sides of the Pyrenees. Quaternary International, 247, 182-198.

Tomasso, A., Binder, D., Martino, G., Porraz, G., \& Simon, P. (2016). Entre Rhône et Apennins : Le référentiel MP-ALP, matières premières de Provence et de l'arc Liguro-provençal. In A. Tomasso, D. Binder, G. Martino, G. Porraz, P. Simon, \& N. Naudinot (Eds.), Ressources lithiques, productions et transferts entre Alpes et Méditerranée (pp. 11-44). Paris: Séances de la Société préhistorique française.

Tozzi, C. (1963). Scavi nella Grotta di Santa Lucia (Toirano). Rivista di Studi Liguri, 1-4, 221-242.

Turq, A. (1992). Le Paléolithique inférieur et moyen entre les vallées de la Dordogne et du Lot. Unpublished PhD. Dissertation, Université Bordeaux, Bordeaux.

Turq, A., Faivre, J. P., Goldberg, P., McPherron, S., \& Sandgathe, D. (2008). Le Moustérien du Périgord Noir: quoi de neuf?. In J. Jaubert, J. G. Bordes, \& I. Ortega (Eds.), Les sociétés du Paléolithique dans un Grand Sud-ouest de la France : Nouveaux gisements, nouveaux résultats, nouvelles méthodes (pp. 89-93). Journées SPF, Université Bordeaux 1, Talence.

Turq, A., Roebroeks, W., Bourguignon, L., \& Faivre, J. P. (2013). The fragmented character of Middle Palaeolithic stone tool technology. Journal of Human Evolution, 65, 641-655. 
Valensi, P., \& Psathi, E. (2004). Faunal exploitation during the Middle Palaeolithic in South-eastern France and North-western Italy. International Journal of Osteoarchaeology, 14, 256-272.

Vallverdú, J., Vaquero, M., Cáceres, I., Allué, E., Rosell, J., Saladié, P., et al. (2010). Sleeping activity area within the site structure of archaic human groups: Evidence from Abric Romaní Level N combustion activity areas. Current Anthropology, 51, 137-145.

Vaquero, M. (2008). The history of stones: Behavioural inferences and temporal resolution of an archaeological assemblage from the Middle Palaeolithic. Journal of Archaeological Science, 35, 3178-3185.

Vaquero, M. (2011). New perspectives on recycling of lithic resources using refitting and spatial data. Quartär, 58, 113-130.

Vaquero, M., Bargalló, A., Chacón, M. G., Romagnoli, F., \& Sañudo, P. (2015). Lithic recycling in a Middle Paleolithic expedient context: Evidence from the Abric Romaní (Capellades, Spain). Quaternary International, 361, 212-228.

Vaquero, M., Chacón, M. G., García-Antón, M. D., Gómez, R., Martínez, K., \& Cuartero, F. (2012). Time and space in the formation of lithic assemblages: The example of Abric Romaní Level. Journal of Quaternary International, 247, 162-181.

Vaquero, M., Chacón, M. G., \& Rando, J. M. (2007). The interpretative potential of lithic refits in a Middle Paleolithic site: The Abric Romaní (Capellades, Spain). In U. Schurmans \& M. de Bie (Eds.), Fitting rocks: Lithic refitting examined. BAR International Series S1596 (pp. 75-89). Oxford: British Archaeological Reports.

Vaquero, M., Fernández-Laso, M. C., Chacón, M. G., Romagnoli, F., Rosell, J., \& Sañudo, P. (2017). Moving things: Comparing lithic and bone refits from Middle Paleolithic. Journal of Anthropological Archaeology, 48, 262-280.

Vaquero, M., \& Pastó, I. (2001). The definition of spatial units in Middle Palaeolithic sites: The hearthrelated assemblages. Journal of Archaeological Science, 28, 1209-1220.

Vaquero, M., \& Romagnoli, F. (2018). Searching for lazy people: The significance of expedient behavior in the interpretation of Paleolithic assemblages. Journal of Archaeological Method and Theory, 25, 334-367.

Vaquero, M., Vallverdú, J., Rosell, J., Pastó, I., \& Allué, E. (2001). Neandertal Behavior at the Middle Palaeolithic site of Abric Romaní, Capellades, Spain. Journal of Field Archaeology, 28, 93-114.

Vicente, M., Martínez Valle, R., Guillem, P., Garay, P., Pueyo, E., \& Casabó, J. (2015). The Lower Palaeolithic site Alto de las Picarazas (Andilla-Chelva, Valencia). Quaternary International, 393, 83-94.

Villaluenga, A. (2009). Yacimientos del Pleistoceno Superior en la Península Ibérica con presencia de restos de oso. Munibe, 60, 17-33.

Villaverde, V. (1984). La Cova Negra de Xàtiva y el Musteriense de la región central del Mediterráneo español. Serie de Trabajos Varios 79. Valencia: Servicio de Investigación Prehistórica, Diputación Provincial de Valencia.

Villaverde, V. (1992). El Paleolítico en el País Valenciano. In P. Utrilla (Ed.), Aragón, Litoral Mediterráneo, Intercambios culturales durante la prehistoria (pp. 55-87). Zaragoza: Institución Fernando el Católico.

Villaverde, V., Eixea, A., Rios, J., \& Zilhão, J. (2012). Importancia y valoración de la producción microlevallois en los niveles II y III del Abrigo de la Quebrada (Chelva, Valencia) (pp. 13-32). LXX: Zephyrus.

Villaverde, V., Eixea, A., \& Zilhão, J. (2008). Aproximación a la industria lítica del Abrigo de la Quebrada (Chelva, Valencia). Treballs d'Arqueologia, 14, 213-228.

Villaverde, V., Eixea, A., Zilhão, J., Sanchis, A., Real, C., \& Bergadà, M. (2017). Diachronic variation in the Middle Paleolithic settlement of Abrigo de la Quebrada (Chelva, Spain). Quaternary International, 435, 164-179.

Villaverde, V., Guillem, P., Martínez-Valle, R., \& Eixea, A. (2014). Cova Negra. In E. Carbonell, J. M. Bermúdez de Castro, \& J. L. Arsuaga (Eds.), Pleistocene and Holocene hunter-gatherers in Iberia and the Gibraltar Strait: The current archaeological record (pp. 361-369). Burgos: Fundación Atapuerca y Universidad de Burgos.

Villaverde, V., \& Martínez Valle, R. (1992). Economía y aprovechamiento del medio en el Paleolítico de la región central del Mediterráneo español. In A. Moure (Ed.), Elefantes, ciervos y ovicaprinos. Economía y aprovechamiento del medio en la Prehistoria de España y Portugal (pp. 77-95). Santander: Universidad de Cantabria. 
Villaverde, V., Martínez-Valle, R., \& Blasco, R. (2009). Análisis de la industria lítica y de la economía: Aproximación al uso del espacio. In V. Villaverde, J. Pérez Ballester, \& A. Ledo (Eds.), Historia de Xàtiva: Prehistoria, arqueología y antigüedad (pp. 147-193). Xàtiva: Universitat de València.

Villaverde, V., Martínez Valle, R., Guillem, P., \& Fumanal, M. P. (1996). Mobility and the role of small game in the Middle Paleolithic of the central region of the Spanish Mediterranean: A comparasion of Cova Negra with other Paleolithic deposits. In E. Carbonell \& M. Vaquero (Eds.), The last Neanderthals, the first Anatomically Modern Humans. Cultural change and human evolution: The crisis at 40 ka BP (pp. 267-288). Tarragona: Universitat Rovira i Virgili.

Wallace, I. J., \& Shea, J. J. (2006). Mobility patterns and core technologies in the Middle Paleolithic of the Levant. Journal of Archaeological Science, 33, 1293-1309.

Zilhão, J., \& Villaverde, V. (2008). The Middle Paleolithic of Murcia. Treballs d'Arqueologia, 14, 229-248.

Publisher's Note Springer Nature remains neutral with regard to jurisdictional claims in published maps and institutional affiliations.

\section{Affiliations}

\section{Aleix Eixea ${ }^{1,2}$. María Gema Chacón ${ }^{3,4,5,6}$. Amèlia Bargalló ${ }^{7}$. Alfred Sanchis ${ }^{8}$. Francesca Romagnoli ${ }^{9} \cdot$ Manuel Vaquero $^{3,4} \cdot$ Valentín Villaverde $^{1,2}$}

1 Departament de Prehistòria, Arqueologia i Història Antiga, Universitat de València, Av. Blasco Ibañez 28, 46010 Valencia, Spain

2 PREMEDOC (GIUV2015-213), Valencia, Spain

3 IPHES - Institut Català de Paleoecologia Humana i Evolució Social, Campus Sescelades URV (Edifici W3), 43007 Tarragona, Spain

4 Area de Prehistoria, Universitat Rovira i Virgili (URV), Avinguda de Catalunya 35, 43002 Tarragona, Spain

5 Histoire Naturelle de l'Homme Préhistorique - HNHP - UMR 7194, (CNRS - MNHN - UPVD - Sorbonne Université), 1 rue René Panhard, 75013 Paris, France

6 Musée de l'Homme, 17 Place du Trocadéro, 75016 Paris, France

7 Institute of Archaeology, University College London, 31-34 Gordon Square, London WC1H OPY, UK

8 Museu de Prehistòria de València, Servei d'Investigació Prehistòrica, Diputació de València, Corona 36, 46003 Valencia, Spain

9 Departamento de Prehistoria y Arqueología, Universidad Autónoma de Madrid, Carretera de Colmenar Viejo, Km 15, Cantoblanco, 28049 Madrid, Spain 